\title{
Tribulus terrestris Ameliorates Oxidative Stress-Induced ARPE-19 Cell Injury through the PI3K/Akt-Nrf2 Signaling Pathway
}

\author{
Zhenli Yuan $\mathbb{D}^{1}{ }^{1}$ Weiwei Du $\mathbb{D}^{1},{ }^{1}$ Xiangdong He $\mathbb{D}^{1},{ }^{1}$ Donglei Zhang $\mathbb{D}^{1},{ }^{1}$ and Wei He $\mathbb{D}^{1,2}$ \\ ${ }^{1}$ The School of Pharmacy, He University, Shenyang 110163, China \\ ${ }^{2}$ Shenyang Industrial Technology Institute of Ophthalmology, Shenyang 110163, China
}

Correspondence should be addressed to Donglei Zhang; zhangdonglei@huh.edu.cn and Wei He; hewei@huh.edu.cn

Received 26 March 2020; Revised 4 June 2020; Accepted 26 June 2020; Published 28 July 2020

Guest Editor: Felipe L. de Oliveira

Copyright (c) 2020 Zhenli Yuan et al. This is an open access article distributed under the Creative Commons Attribution License, which permits unrestricted use, distribution, and reproduction in any medium, provided the original work is properly cited.

\begin{abstract}
Oxidative stress on retinal pigment epithelial (RPE) cells has been confirmed to play a crucial role in the development and progression of age-related macular degeneration (AMD) or other retinal degenerative diseases. Tribulus terrestris (TT) is a Chinese traditional herb medicine, which has been used for the treatment of ocular diseases for many centuries. In this study, we investigated the underlying mechanisms of TT and examined its ability to protect and restore the human retinal pigment epithelial cells (ARPE-19) against $\mathrm{H}_{2} \mathrm{O}_{2}$-induced oxidative stress. Our data show that $200 \mu \mathrm{g} / \mathrm{mL}$ of ethanol extract of Tribulus terrestris (EE-TT) significantly increased the cell viability and prevented the apoptosis of $\mathrm{H}_{2} \mathrm{O}_{2}$-treated ARPE-19 cells through the regulation of $\mathrm{Bcl} 2$, Bax, cleaved caspase-3, and caspase-9. Treatment with EE-TT also significantly decreased the upregulated reactive oxygen species (ROS) activities and increased the downregulated superoxide dismutase (SOD) activities induced by $\mathrm{H}_{2} \mathrm{O}_{2}$ in ARPE-19 cells. Additionally, $\mathrm{H}_{2} \mathrm{O}_{2}$ at $1 \mathrm{mM}$ significantly decreased the mRNA expression levels of Nrf2, CAT, SOD1, SOD2, HO-1, GST-pi, NQO1, and GLCM in ARPE-19 cells; however, treatment with EE-TT reversed the downregulated mRNA expression levels of all these genes induced by $\mathrm{H}_{2} \mathrm{O}_{2}$. Furthermore, treatment with $200 \mu \mathrm{g} / \mathrm{mL}$ EE-TT alone for $24 \mathrm{~h}$ significantly increased Nrf2, HO-1, NQO1, and GCLM mRNA expressions in ARPE-19 cells when compared with untreated control cells. Pretreatment with the inhibitor of PI3K/Akt signaling (LY294002) completely blocked these EE-TT-upregulated mRNA expressions and abolished the improvement of cell viability in $\mathrm{H}_{2} \mathrm{O}_{2}$-treated ARPE-19 cells. These findings all suggest that Tribulus terrestris has significant antioxidant effects on oxidative stressed ARPE-19 cells through regulating PI3K/Akt-Nrf2 signaling pathway.
\end{abstract}

\section{Introduction}

Numerous studies have shown that visual impairment caused by retinal damage is among one of the most important causes of blindness, in particular, pathological retinal pigment epithelial cell layer damage in age-related macular degeneration (AMD) and other retinal diseases (such as diabetes and retinitis pigmentosa) $[1,2]$. Therefore, protecting RPE cells from injury or delaying RPE cell damage is important in AMD treatment.

The human retinal pigment epithelial (RPE) is a monolayer of pigmented cells lying in the interface between the photoreceptors of the neurosensory retina and the choroidal capillary bed; it constitutes the outer blood-retinal barrier preventing the entrance of toxic molecules and plasma com- ponents into the retina [3]. The RPE cell layer plays an important role due to its unique location, which enables it to protect fundus tissue against photooxidation, as well as its function that allows it to process visual cycle [4]. Under normal physiological conditions, the retina demands higher oxygen supply against the high levels of cumulative irradiation surrounding the retinal, which render RPE cells vulnerable to oxidative damage. Reactive oxygen species (ROS) induced by oxidative stress is the main cellular reactive oxygen intermediates, which include free radicals, hydrogen peroxide, and oxygen ion from the byproducts of oxygen metabolism, inducing cell damage and apoptosis in the different cell types $[5,6]$. In normal cells, an accurate balance between ROS generation and antioxidant systems maintains cellular redox homeostasis. The cellular antioxidant systems 
include the enzymatic antioxidants and the nonenzymatic antioxidants. The enzymatic antioxidants mainly consist of superoxide dismutases (SODs), catalase (CAT), heme oxidase (HO-1), glutathione S-transferases pi (GST-pi), $\mathrm{NAD}(\mathrm{P}) \mathrm{H}$ quinoneoxidoreductase (NQO1), glutamatecysteine ligase modifier subunit (GCLM), glutathione peroxidases (GPXs), and reductase (GR) [7-9]; the endogenous nonenzymatic antioxidants include ascorbic acid (vitamin $\mathrm{C})$, glutathione $(\mathrm{GSH})$, reduced nicotinamide-adenine dinucleotide phosphate (NADPH), and $\alpha$-tocopherol (the most active form of vitamin E) [10].

A growing number of studies have fully illustrated that the nuclear factor erythroid 2-related factor 2 (Nrf2) functions as the master regulator in the antioxidant stress pathway in mammal cells. Under basal conditions, NRF2 physically binds to the negative regulator Kelch-like ECH2associated protein 1 (Keap1) for ubiquitination and proteasomal degradation within the cytoplasm, thus limiting Nrf2 activation (translocation to the nuclear) $[11,12]$. However, under oxidative circumstances, Nrf2 is released from Keap1 and translocate into the nucleus, where it binds to antioxidant response elements (AREs), thus activating transcription of its target genes encoding phase II metabolizing enzymes and antioxidases, as well as molecular chaperones and antiinflammatory factors [13-15]. Therefore, the Nrf2-ARE pathway has been one of the most important endogenous antioxidant stress pathway discovered to date. Furthermore, there has been evidence that Nrf2-deficient mice developed ocular pathology similar to cardinal features of human AMD and deregulated autophagy; there is likely a mechanistic link between oxidative injury and inflammation [16-20].

Tribulus terrestris (TT) is a plant that belongs to the family of Zygophyllaceae, and it is used individually as a single therapeutic agent or as a prime or subordinate component of many compound formulations and food supplements (health food) in China. The dry fruits of TT, as a traditional herb medicine (commonly named "Ji Li"), have been used for more than thousands of years in China within the context of protecting the liver, activating blood circulation, improving eyesight, and relieving itching (Chinese Pharmacopoeia, 2015 version). Modern studies have shown that TT has various pharmacological effects including anti-inflammatory, antioxidant, antibacterial, antiaging, and antitumor activities $[21,22]$. TT has been used in clinical therapy, especially for the prevention and treatment of cardiovascular diseases, eye diseases, improving male sexual function, and diabetes [2325]. The chemical constituents of the fruit of TT mainly include saponins, flavonoids, and alkaloids (polysaccharides, amino acids, and vitamins); the studies have shown that saponins and flavonoids in TT mainly contribute to its pharmacological activities.

For the first time, our present study investigates the underlying mechanisms of Tribulus terrestris (TT), which enables it to protect and restore the human retinal pigment epithelial cells (ARPE-19) against oxidative stress. Our results revealed that Tribulus terrestris (TT) has a significant antioxidant and cytoprotective effects on $\mathrm{H}_{2} \mathrm{O}_{2}$-treated ARPE-19 cells functioning through the PI3K/Akt-Nrf2 signaling pathway.

\section{Materials and Methods}

2.1. Cells and Cell Culture. Human RPE cell line (ARPE-19) was obtained from ATCC (American Type Culture Collection). Cells were cultured in GIBCO Dulbecco's Modified Eagle Medium. The medium was supplemented with $10 \%$ fetal bovine serum, $100 \mu \mathrm{g} / \mathrm{mL}$ of streptomycin, and $100 \mathrm{U} / \mathrm{mL}$ of penicillin at $37^{\circ} \mathrm{C}$ with $5 \% \mathrm{CO}_{2}$ in a humidified atmosphere; and the medium was changed every other day.

\subsection{Preparation of the Ethanol Extracts of Tribulus terrestris} (EE-TT). First, Chinese herbal medicine of Tribulus terrestris (TT, dry fruits from the plant of Tribulus terrestris L. in China) $20 \mathrm{~g}$ was extracted by refluxing at $80^{\circ} \mathrm{C}$ in $200 \mathrm{~mL}$ of $70 \%$ ethanol and then the filtrate was collected twice for 1.5 hours each time. Then, the combined filtrate was adsorbed by the macroporous adsorbed resin column and then eluted with water and 95\% ethanol in turn. Finally, $1.36 \mathrm{~g}$ of ethanol extract from Tribulus terrestris (EE-TT) was obtained by collecting of $95 \%$ ethanol eluted solution and recovering ethanol under the reduced pressure.

2.3. Cell Viability Assay and Oxidative Injury Model in ARPE19 Cells. ARPE-19 cells viabilities were evaluated using 3(4,5-dimethylthiazol-2-yl)-5-(3-carboxymethoxyphenyl)-2(4-sulfophenyl) -2H-tetrazolium (MTS) reagent according to the manufacturer's instruction (Promega, USA). First, cells were plated in 96-well microplate with $2 \times 10^{4}$ cells/well. Then, the cells were treated with individual concentration of $\mathrm{H}_{2} \mathrm{O}_{2}$ or ethanol extracts of Tribulus terrestris (EE-TT) for $24 \mathrm{~h}$; or the cells were treated with $1 \mathrm{mM} \mathrm{H}_{2} \mathrm{O}_{2}$ for $24 \mathrm{~h}$ then followed by another $24 \mathrm{~h}$ exposure to the individual concentration of EE-TT; or the cells were treated with individual concentration of EE-TT for $4 \mathrm{~h}$ then followed by another $24 \mathrm{~h}$ exposure to $1 \mathrm{mM} \mathrm{H}_{2} \mathrm{O}_{2}$, respectively. $5 \mathrm{mg} / \mathrm{mL}$ MTS solution was added $(20 \mu \mathrm{L} /$ well $)$, and the cells were incubated for $4 \mathrm{~h}$ at $37^{\circ} \mathrm{C}$. Last, the absorbance was measured at $492 \mathrm{~nm}$ by a microplate reader (MD Emax Plus, USA). All experiments were performed in triplicate, and in each experiment, a minimum of three wells per treatment were used. The viability of ARPE-19 cells in each well was presented as the percentage of control cells (nontreated normal cells).

2.4. Apoptosis Assay of ARPE-19 Cells. The Annexin VFITC/Propidium Iodide (PI) double-staining assay was used to detect cell apoptosis in this study. ARPE-19 cells were grown on a six-well plate at $1 \times 10^{5}$ cells/well, and cells were either treated with or without different concentrations of TT for $24 \mathrm{~h}$ at $37^{\circ} \mathrm{C}$ after treatment with $1 \mathrm{mM} \mathrm{H}_{2} \mathrm{O}_{2}$ for $24 \mathrm{~h}$ at $37^{\circ} \mathrm{C}$ with $5 \% \mathrm{CO} 2$. The cells were washed twice and collected with PBS (137 mM NaCl, $2.7 \mathrm{mM} \mathrm{KCl,} 4.3 \mathrm{mM} \mathrm{Na}_{2} \mathrm{HPO}_{4}$, and $1.4 \mathrm{mM} \mathrm{KH}_{2} \mathrm{PO}_{4}$ ). The cells were trypsinized and stained with annexin V-FITC and PI (from annexin V-FITC apoptosis detection kit, Nanjing Jiancheng Biology Engineering Research Institute, Nanjing, China) according to the manufacturer's protocol. The fluorescence intensity was measured by flow cytometry (FACSCalibur, BD Biosciences, San Diego, CA, USA). The cells were divided into viable cells (annexin V $-/ \mathrm{PI}-$ ), early apoptotic cells (annexin V+/PI-), late apoptotic cells (annexin $\mathrm{V}+/ \mathrm{PI}+$ ), and necrotic cells (annexin $\mathrm{V}-/ \mathrm{PI}+$ ). 
TABLE 1: The primer sequences for real-time quantitative PCR.

\begin{tabular}{lcc}
\hline Gene name & Forward $\left(5^{\prime}-3^{\prime}\right)$ & Primer sequences \\
\hline NRF2 & TTCTCCCAATTCAGCCAGCC $\left(5^{\prime}-3^{\prime}\right)$ \\
CAT & ACTGTTGCTGGAGAATCGGG & ACGTAGCCGAAGAAACCTCAT \\
SOD 1 & TGAAGGTGTGGGGAAGCATT & AGGACGTAGGCTCCAGAAGT \\
GST $-\mathrm{pi}$ & GCATCAGCGGTAGCACCA & AGTCTCCAACATGCCTCTCTTC \\
$\mathrm{HO}-1$ & AGACCAGATCTCCTTCGCTG & TGGGCTGTAACATCTCCCTTG \\
NQO1 & ACTGCGTTCCTGCTCAACAT & AGGTTCACGTACTCAGGGGA \\
GCLM & GGTTTGGAGTCCCTGCCATT & GGGCAGAATCTTGCACTTTGTT \\
ACTB & CAGCGAGGAGGAGTTTCCAG & CCTTCTTACTCCGGAAGGGTC \\
\hline
\end{tabular}

The stained cells were then analyzed with Cell-Quest software.

2.5. Measurement of Intracellular Reactive Oxygen Species (ROS). The activities of ROS in ARPE-19 cells were detected by reactive oxygen species assay kit (Nanjing Jiancheng Biological Research Institute, China) following the manufacturer's directions. The cells were incubated with $10 \mu \mathrm{M}$ $\mathrm{DCFH}-\mathrm{DA}$ reagent from the kit for $30 \mathrm{~min}$ at $37^{\circ} \mathrm{C}$ before being washed and suspended in PBS at $1 \times 10^{6}$ cells $/ \mathrm{mL}$. Then, the cells were analyzed using flow cytometry at excitation and emission wavelengths of 488 and $525 \mathrm{~nm}$, respectively. The untreated cells served as the control sample. The results were expressed as the mean of fluorescence intensity (MFI) of dichlorofluorescein (DCF) [26].

2.6. Measurement of Intracellular Superoxide Dismutase (SOD) Activity. The activities of SOD in ARPE-19 cells were detected using a superoxide dismutase assay kit (Nanjing Jiancheng Biological Research Institute, China). First, ARPE-19 cells were pretreated with $1 \mathrm{mM} \mathrm{H}_{2} \mathrm{O}_{2}$ for $24 \mathrm{~h}$; or followed by a $24 \mathrm{~h}$ exposure to ethanol extracts of Tribulus terrestris (EE-TT). Then, the cells were repeatedly frozen and thawed several times in order to make sure the cells were thoroughly broken. Lastly, activities of SOD in ARPE-19 cells were detected to assess the antioxidative capacities (unit/per mg protein) using the superoxide dismutase assay kit following the manufacturer's directions [27].

2.7. Total Antioxidant Capacity Assay. Ferric reducing antioxidant power (FRAP) assay is a reliable and simple method for evaluating the inhibiting ability of antioxidants in the Fenton reaction [27]. The experiment was performed according to the protocol of the FRAP assay kit (Beyotime, Shanghai, China). The values of absorbance-concentrations of $\mathrm{FeSO}_{4}$ were used to make a standard curve, and the total antioxidant capacity was calculated as the concentration of $\mathrm{FeSO}_{4}$. The certain concentrations of positive antioxidant control Trolox (an analogue of vitamin E) or the ethanol extracts of Tribulus terrestris (EE-TT) were added in the reaction system, respectively. The reaction solution was incubated at $37^{\circ} \mathrm{C}$ for $3-5$ minutes, and the value of absorbance was detected at $595 \mathrm{~nm}$. The total antioxidant capacity of
EE-TT or Trolox was calculated according to the standard curve of $\mathrm{FeSO}_{4}$.

2.8. Real-Time Quantitative PCR. Total RNA was extracted from ARPE-19 cells using TRIzol Reagent (Invitrogen, USA), and the cDNA was synthesized using GoScript ${ }^{\mathrm{TM}}$ Reverse Transcription System (Promega, USA) from $2 \mu \mathrm{g}$ RNA for each sample. Real-time PCR was performed using a GoTaq ${ }^{\circledR}$ qPCR Master Mix (Promega, USA) as follows: $20 \mu \mathrm{L}$ reaction solution contained $10 \mu \mathrm{L}$ SYBR Mix, $0.4 \mu \mathrm{L}$ sense and $0.4 \mu \mathrm{L}$ antisense primers solution (from $10 \mu \mathrm{M}$ ), $1 \mu \mathrm{L}$ diluted $\mathrm{cDNA}$, and $8.2 \mu \mathrm{L}$ nuclease-free water. The primer sequences used for real-time quantitative PCR are shown in Table 1 below. The subsequent data analysis was performed using MxPro ${ }^{\mathrm{TM}}$ QPCR Software followed by comparative quantification real-time PCR. The relative change in gene expression was determined according to the $2^{-\Delta \Delta \mathrm{CT}}$ formula in which gene expression was normalized to the expression of $\beta$-actin $(A C T B)$ in treated and untreated control samples.

2.9. Western Blot Analysis. The total proteins of ARPE-19 cells with or without treatments were collected and lysed in a buffer containing $50 \mathrm{mM}$ Tris- $\mathrm{HCl}$ (pH 7.5), $150 \mathrm{mM} \mathrm{NaCl}$, $2 \mathrm{mM}$ EDTA, 1\% Triton, $1 \mathrm{mM}$ PMSF, and protease inhibitor cocktail on ice with rotation of $30 \mathrm{~min}$. In order to examine Nrf2 expression, nuclear proteins or cytoplasmic proteins were isolated using a Bioepitope Nuclear Kit or Cytoplasmic Extraction Kit (Wanleibio, China) according to the protocol. The protein lysates ( $40 \mu \mathrm{g}$ of each sample) were separated by $10 \%$ or $12 \%$ sodium dodecyl sulfate- (SDS-) polyacrylamide gel electrophoresis and transferred to polyvinylidene difluoride (PVDF) membranes, which were blocked with primary and secondary antibodies according to the method we published previously [27]. The primary antibodies used in this study are as follows: $\mathrm{Bcl} 2$, Bax, cleaved caspase-3, cleaved caspase-9, NRF2, histone $H 3$, and $\beta$-actin $(1: 500$ or $1: 1000$, from Wanleibio, China); HRP-conjugated anti-mouse secondary antibodies (1:5000, from Wanleibio, China) were also used. The bands were visualized using an ECL western blotting detection kit (Beyotime, China) following the recommended procedures and the density of each band was measured using ImageJ software. The protein expression 


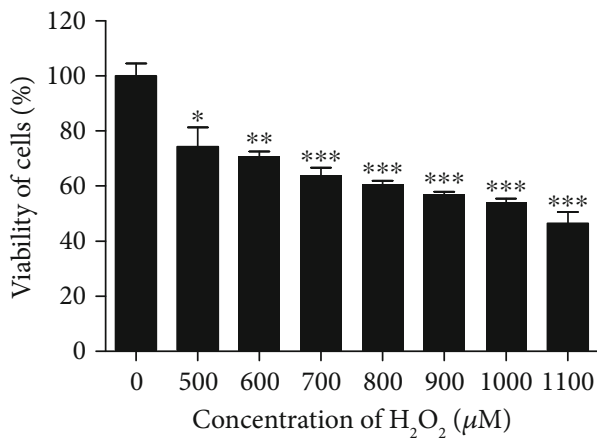

(a)

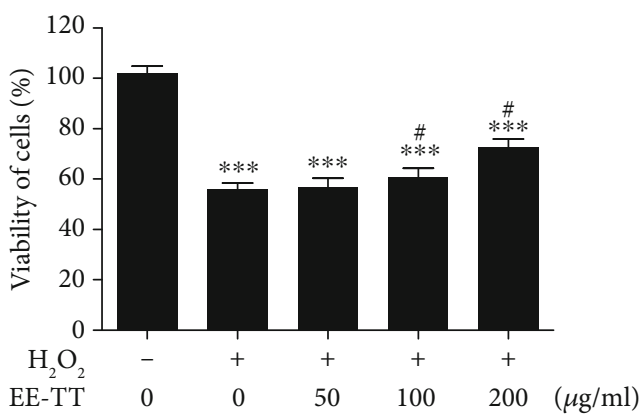

(c)
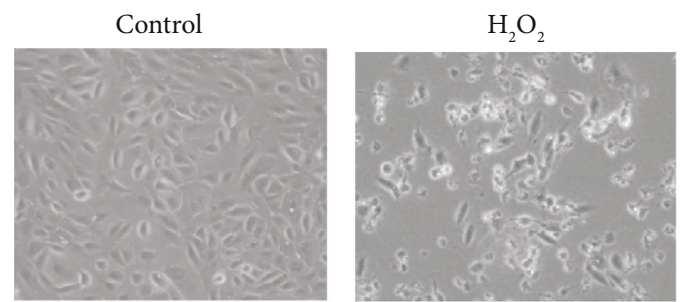

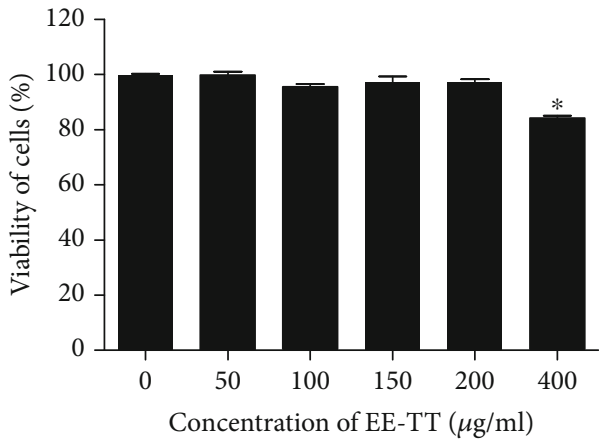

(b)

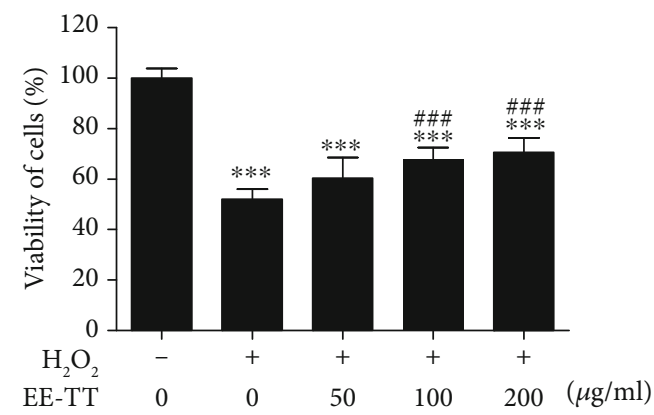

(d)
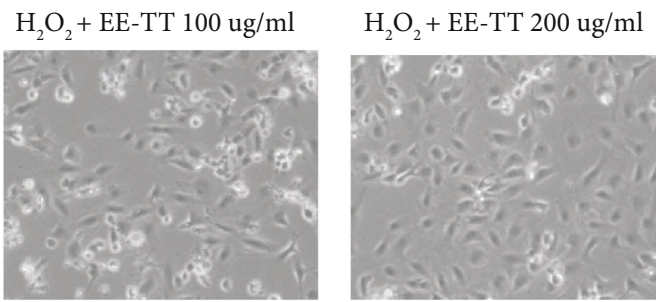

(e)

FIgure 1: EE-TT increased the cell viabilities in $\mathrm{H}_{2} \mathrm{O}_{2}$-treated ARPE-19 cells. (a) ARPE-19 cells were treated with or without individual concentrations of $\mathrm{H}_{2} \mathrm{O}_{2}$, respectively, for $24 \mathrm{~h}$. (b) ARPE-19 cells were treated with individual concentrations of EE-TT for $24 \mathrm{~h}$. (c) ARPE19 cells were pretreated with $1 \mathrm{mM} \mathrm{H}_{2} \mathrm{O}_{2}$ for $24 \mathrm{~h}$, then cells were treated with individual concentrations of EE-TT for another $24 \mathrm{~h}$. (d) ARPE-19 cells were pretreated with individual concentrations of EE-TT for $4 \mathrm{~h}$, then cells were treated with $1 \mathrm{mM} \mathrm{H}_{2} \mathrm{O}_{2}$ for another $24 \mathrm{~h}$. (a-d) The viability of cells was measured by MTS assay; the viability of cells was expressed as a percentage of the control group (nontreated cells). All data are shown as mean $\pm \mathrm{SD},{ }^{*} p<0.05,{ }^{* *} p<0.01$, and ${ }^{* * *} p<0.001$ vs. the samples of control group (nontreated cells); ${ }^{\#} p<0.05$ vs. the samples treated with $\mathrm{H}_{2} \mathrm{O}_{2}$ alone. (e) The cell morphology of ARPE-19 cells (c) was observed under an optic microscope (Nikon ECLIPSE TS100, Japan).

level of each molecular was normalized to $\beta$-actin protein (for total or cytoplasmic protein) or to histone H3 (for nuclear protein) expression level and compared with the untreated control sample, which was assigned to the value of $1[28]$.

2.10. Statistical Analysis. All experiments were performed at least three times. Statistical analysis was carried out by the Statistical Product and Service Solutions (SPSS) software. Data are presented as mean \pm SD (standard deviation). Student's $t$-test was used to calculate statistical significance between 2 groups. Statistical significance is denoted by the following: ${ }^{*} p<0.05,{ }^{* *} p<0.01$, and ${ }^{* * *} p<0.001$; or ${ }^{\#} p<0.05$, $\# p<0.01$, and ${ }^{\# \# \#} p<0.001$.

\section{Results}

3.1. Tribulus terrestris Increased the Cell Viabilities in $\mathrm{H}_{2} \mathrm{O}_{2}$ Treated ARPE-19 Cells. In this study, we used a $\mathrm{H}_{2} \mathrm{O}_{2}$ induced oxidative stress model in ARPE- 19 cells. After $24 \mathrm{~h}$ treatment with the individual concentrations of $\mathrm{H}_{2} \mathrm{O}_{2}$, the cell viabilities were measured by MTS assay. Figure 1(a) shows that $\mathrm{H}_{2} \mathrm{O}_{2}$ dose-dependently reduced the viability of ARPE-19 cells, and after treatment with $1000 \mu \mathrm{M}(1 \mathrm{mM})$ $\mathrm{H}_{2} \mathrm{O}_{2}$ for $24 \mathrm{~h}$, the cell viability was about $54 \%$ compared with the untreated control sample. Accordingly, $1 \mathrm{mM}$ $\mathrm{H}_{2} \mathrm{O}_{2}$ was used to induce oxidative injury in these cells for subsequent experiments. We also examined the potential toxicity of ethanol extracts of Tribulus terrestris (EE-TT) to 

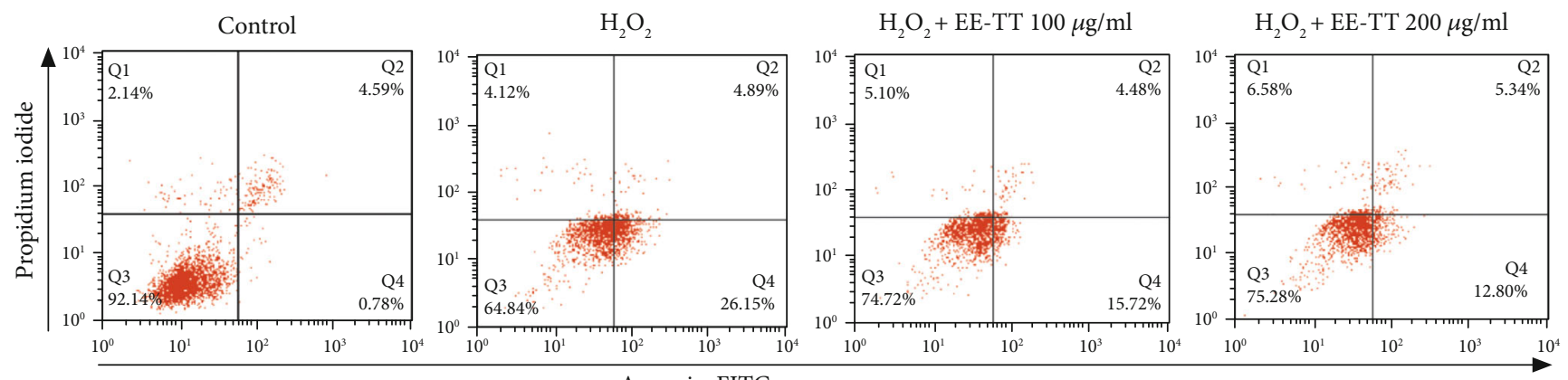

(a)

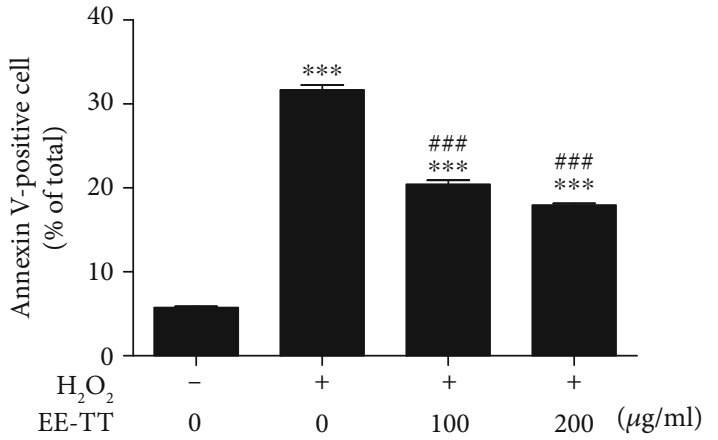

(b)

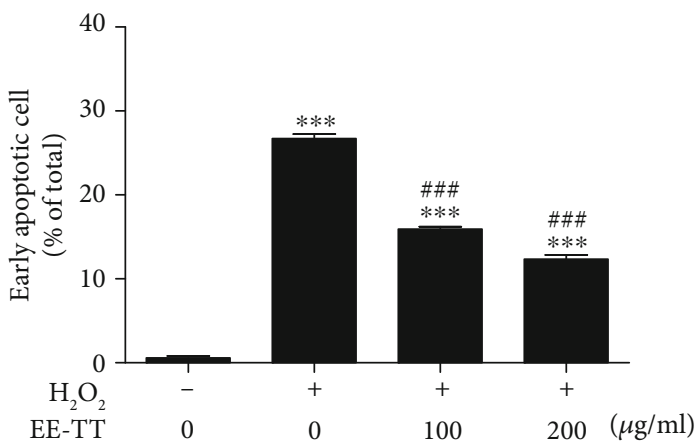

(c)

FIGURE 2: EE-TT inhibited $\mathrm{H}_{2} \mathrm{O}_{2}$-induced apoptosis in ARPE-19 cells. (a) ARPE-19 cells with or without $\mathrm{H}_{2} \mathrm{O}_{2}$ treatment for $24 \mathrm{~h}$, then cells were treated with or without ethanol extracts of Tribulus terrestris (EE-TT) $(100$ or $200 \mu \mathrm{g} / \mathrm{mL})$ for another 24 h, the cells were stained with annexin V-FITC/PI double staining and analyzed by flow cytometry. The percentage of cells in each quadrant is presented. (b) The quantification of annexin V-FITC-positive cells (Q2+Q4) was calculated for each group cells and is shown in the bar graph. (c) The quantification of early apoptotic cells (Q4) was calculated for each group cells and is shown in the bar graph. The data in (b) and (c) are shown as mean $\pm \mathrm{SD},{ }^{*} p<0.05,{ }^{* *} p<0.01,{ }^{* * *} p<0.001$ vs. the samples of control group (nontreated cells); ${ }^{\#} p<0.05,{ }^{\# \#} p<0.01$, $\#$ \#\# 0.001 vs. the samples treated with $\mathrm{H}_{2} \mathrm{O}_{2}$ alone.

ARPE-19 cells and found that there was no significant change in cell viability after $24 \mathrm{~h}$ incubation with EE-TT at 50,100,150, and $200 \mu \mathrm{g} / \mathrm{mL}$ (Figure 1(b)). However, EE-TT at higher concentration $(400 \mu \mathrm{g} / \mathrm{mL})$ had a toxic effect on ARPE-19 cells with a significant decrease in cell viability (Figure 1(b)). Consequently, EE-TT at a concentration of 100 or $200 \mu \mathrm{g} / \mathrm{mL}$ was applied in subsequent experiments. Next, we observed that EE-TT concentration dependently increased cell survival rate in ARPE-19 cells after cells were exposed to $1 \mathrm{mM} \mathrm{H}_{2} \mathrm{O}_{2}$ for $24 \mathrm{~h}$ (Figure 1(c)), and treatment with $200 \mu \mathrm{g} / \mathrm{mL}$ EE-TT for $24 \mathrm{~h}$ significantly increased cell viability from $55.8 \%$ to $72.6 \%$ compared with $\mathrm{H}_{2} \mathrm{O}_{2}$ only treated control sample (Figure 1(c)). In addition, we also observed that EE-TT concentration dependently increased cell survival rate in ARPE19 cells when pretreatment with EE-TT for $4 \mathrm{~h}$ before cells were exposed to $1 \mathrm{mM} \mathrm{H}_{2} \mathrm{O}_{2}$ for $24 \mathrm{~h}$ (Figure $1(\mathrm{~d})$ ), pretreatment with $200 \mu \mathrm{g} / \mathrm{mL}$ EE-TT for $4 \mathrm{~h}$ significantly increased cell viability from $52.1 \%$ to $70.5 \%$ compared with $\mathrm{H}_{2} \mathrm{O}_{2}$ only treated control sample (Figure 1(d)). The cell morphology of ARPE-19 cells (Figure 1(c)) was also observed under an optic microscope (Figure 1(e)). After $\mathrm{H}_{2} \mathrm{O}_{2}$ treatment, ARPE-19 cells became round, smaller, and the brightness of the cells darkened; some cell fragments can be observed under the microscope. While after exposure to EE-TT for $24 \mathrm{~h}$, the number of damaged cells decreased significantly. Taken together, these data collectively indicated that EE-TT could protect and rescue ARPE- 19 cells against $\mathrm{H}_{2} \mathrm{O}_{2}$-induced oxidative injury.

3.2. The Antiapoptotic Effects of Tribulus terrestris on Oxidative Stressed ARPE-19 Cells. To investigate whether Tribulus terrestris protects against $\mathrm{H}_{2} \mathrm{O}_{2}$-induced apoptosis, ARPE-19 cells were incubated with $1 \mathrm{mM} \mathrm{H}_{2} \mathrm{O}_{2}$ for $24 \mathrm{~h}$ and were then exposed to 100 or $200 \mu \mathrm{g} / \mathrm{mL}$ EE-TT for $24 \mathrm{~h}$. Cells were double stained with Annexin V-FITC/PI, and the percentage of apoptotic cells was determined with flow cytometry assay. The distribution of population of annexin V-FITC/PI staining cells is shown in Figure 2(a); the percentage of apoptotic cells (annexin V-FITC positive cells) or early apoptosis cells (annexin V-FITC positive/PI negative cells) was calculated and the results are presented in Figures 2(b) and 2(c), respectively. The results show that treatment with $200 \mu \mathrm{g} / \mathrm{mL}$ EE-TT on ARPE-19 cells significantly reduced the percentage of apoptotic cells from $31.67 \%$ to $18.01 \%$ when compared with $\mathrm{H}_{2} \mathrm{O}_{2}$ alone treated sample, while it reduced the percentage of early apoptotic cells from $26.72 \%$ to $12.35 \%$ when compared with $\mathrm{H}_{2} \mathrm{O}_{2}$ 


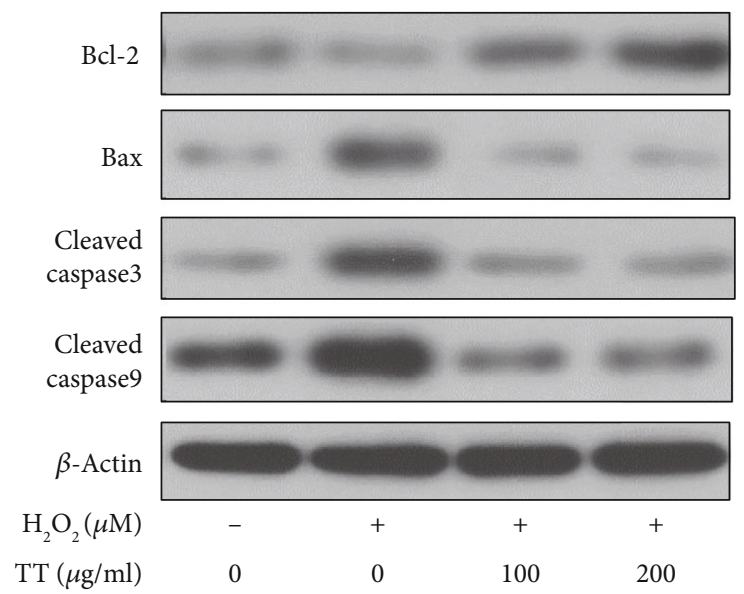

(a)

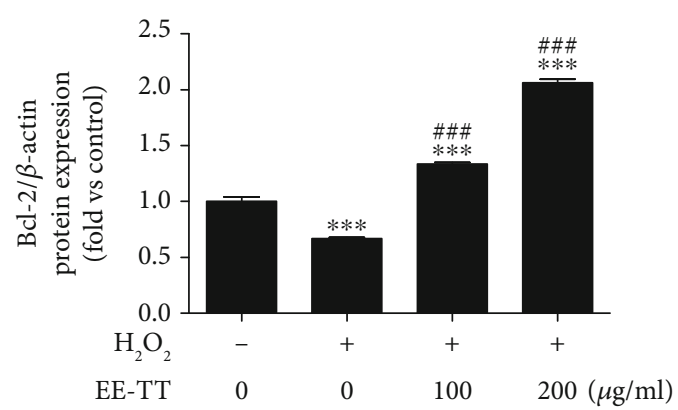

(b)

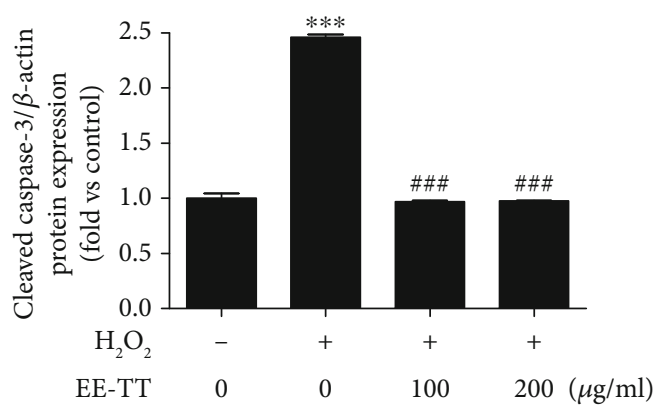

(d)

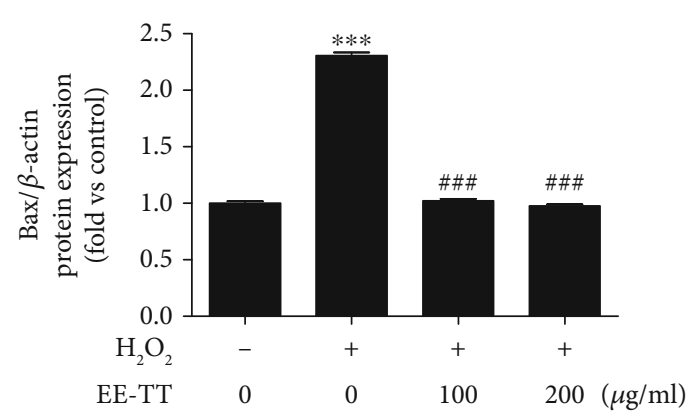

(c)

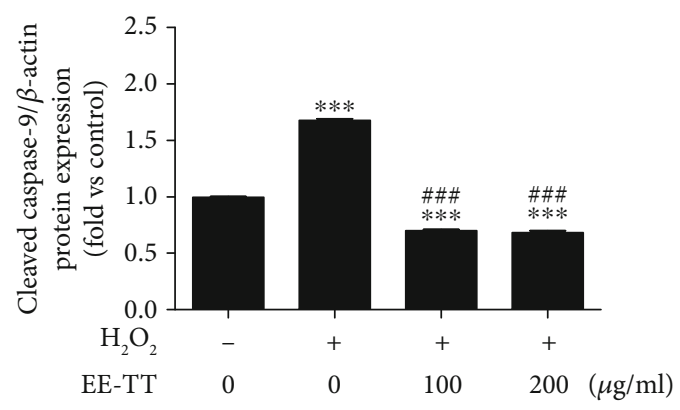

(e)

FIGURE 3: Effects of EE-TT on the protein expression levels of Bcl-2, Bax, caspase-3, and caspase- 9 in $\mathrm{H}_{2} \mathrm{O}_{2}$-treated ARPE-19 cells. ARPE-19 cells were pretreated with or without $1 \mathrm{mM} \mathrm{H}_{2} \mathrm{O}_{2}$ for $24 \mathrm{~h}$, followed by a $24 \mathrm{~h}$ exposure to ethanol extracts of Tribulus terrestris (EE-TT) (100 or $200 \mu \mathrm{g} / \mathrm{mL}$ ). (a) The cell lysates of control (nontreatment), $\mathrm{H}_{2} \mathrm{O}_{2}$-treated alone, or $\mathrm{H}_{2} \mathrm{O}_{2}$ plus EE-TT-treated samples were analyzed by Western blot assay with the antibodies of Bcl-2, Bax, cleaved caspase-3, cleaved caspase-9, and $\beta$-actin, respectively. Quantification data of these protein expression levels were measured and normalized to $\beta$-actin expression levels. The fold changes vs. control sample (nontreatment) were presented in the bar graph from (b-e), respectively. Data are shown as mean $\pm \mathrm{SD},{ }^{*} p<0.05,{ }^{* *} p<0.01,{ }^{* * *} p<0.001$ vs. the nontreatment control sample; ${ }^{\#} p<0.05,{ }^{\# \#} p<0.01$, ${ }^{\# \# \#} p<0.001$ vs. the sample with $\mathrm{H}_{2} \mathrm{O}_{2}$ treatment alone, $n=3$.

alone treated sample. These results show that EE-TT could effectively protect and rescue ARPE-19 cells from $\mathrm{H}_{2} \mathrm{O}_{2}$ induced apoptotic cell damage.

Several studies have reported that $\mathrm{H}_{2} \mathrm{O}_{2}$-induced ARPE19 cells apoptosis is related to the mitochondrial apoptotic signaling which involves the proapoptotic protein Bax, the antiapoptotic protein $\mathrm{Bcl}-2$, and the downstream protein caspase families $[29,30]$. We thus investigated and confirmed the possible mechanisms of the antiapoptotic effect of Tribulus terrestris on $\mathrm{H}_{2} \mathrm{O}_{2}$-treated ARPE-19 cells. The protein expression levels of $\mathrm{Bcl} 2$, Bax, caspase-3, and caspase-9 were measured by Western blot assay in $\mathrm{H}_{2} \mathrm{O}_{2}$-treated ARPE-19 cells followed by exposure to EE-TT for $24 \mathrm{~h}$ (Figure 3(a)). The fold changes of these protein expressions were calculated and presented in Figures 3(b)-3(e) bar graph. The results show that treatment with $200 \mu \mathrm{g} / \mathrm{mL}$ EE-TT on ARPE-19 cells decreased the upregulated Bax, cleaved caspase-3, and cleaved caspase- 9 protein expression levels induced by $\mathrm{H}_{2} \mathrm{O}_{2}$ around $60 \%$, and meanwhile, treatment with $200 \mu \mathrm{g} / \mathrm{mL}$ EE-TT on ARPE-19 cells increased the downregulated Bcl-2 protein expression levels induced by $\mathrm{H}_{2} \mathrm{O}_{2}$ about $207 \%$. These results indicate that EE-TT protects 

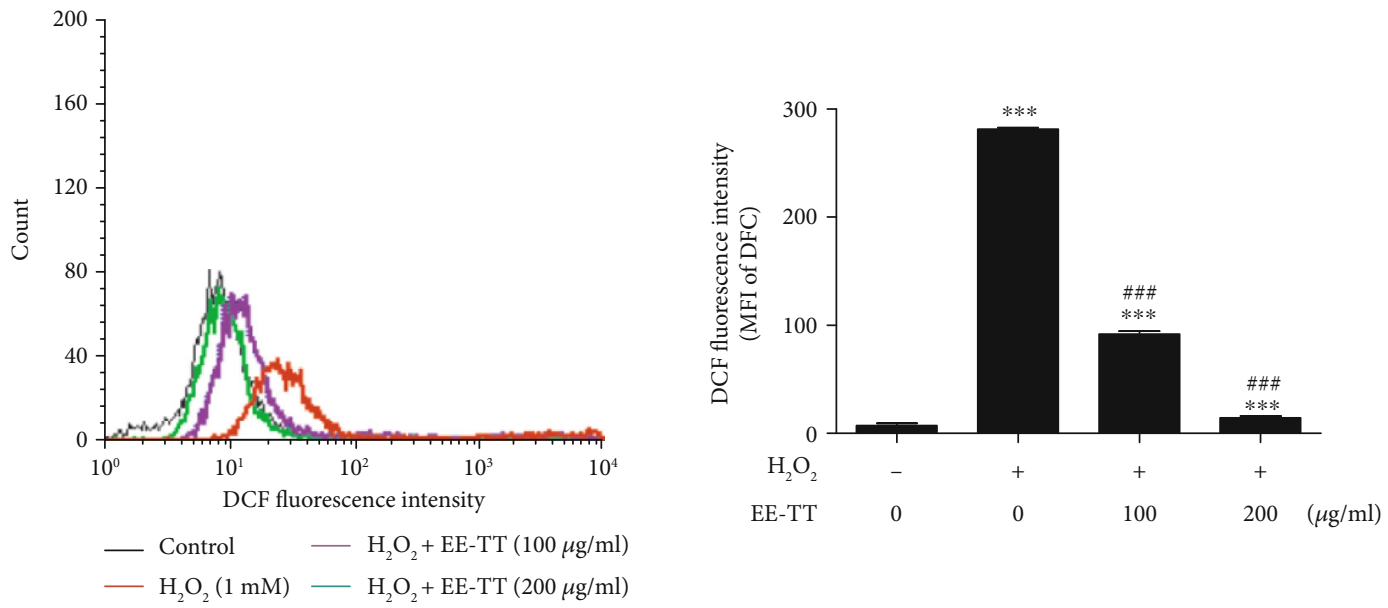

(a)
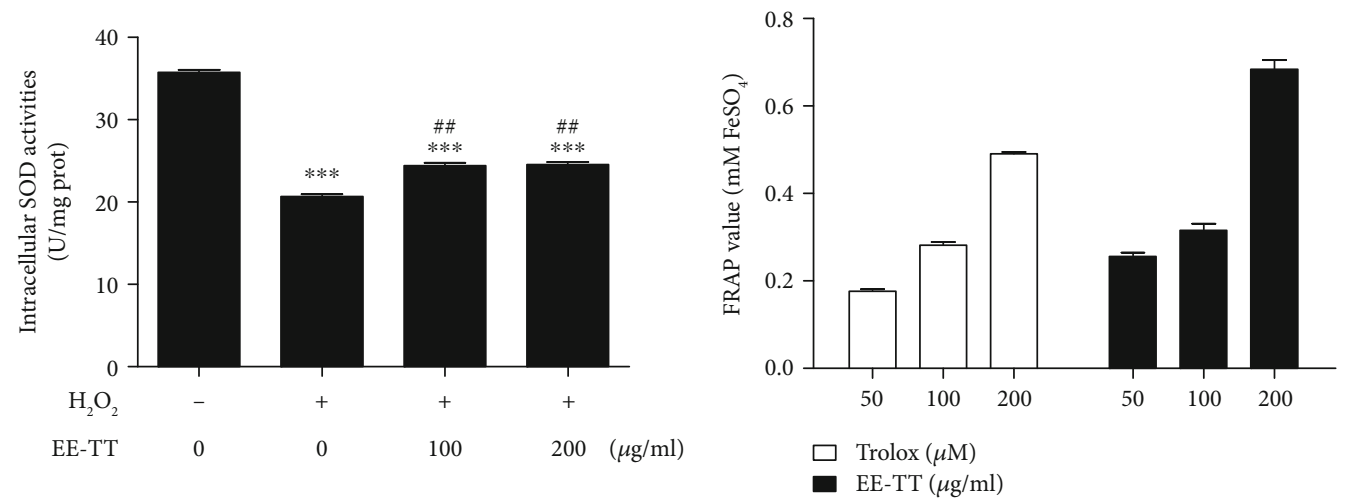

(b)

(c)

FIGURE 4: EE-TT significantly reduced the ROS activity while increasing SOD activity in $\mathrm{H}_{2} \mathrm{O}_{2}$-treated ARPE-19 cells. ARPE-19 cells were pretreated with or without $1 \mathrm{mM} \mathrm{H}_{2} \mathrm{O}_{2}$ for $24 \mathrm{~h}$, followed by a $24 \mathrm{~h}$ exposure to ethanol extracts of Tribulus terrestris (EE-TT): (a) The intracellular ROS activities were measured and analyzed by a flow cytometer. ROS activity of each sample was presented by the mean of fluorescence intensity (MFI) of DCF; (b) The activities of intracellular SOD were measured by a SOD activity assay kit. The SOD levels were normalized against per milligram protein. (c) Comparison of total antioxidant capacity of EE-TT and Trolox (an analogue of vitamin E, a positive antioxidant control). All data are shown as mean $\pm \mathrm{SD}(n=3) .{ }^{*} p<0.05,{ }^{* *} p<0.01,{ }^{* * *} p<0.001$ vs. the samples of control group (nontreated cells); ${ }^{\#} p<0.05,{ }^{\# \#} p<0.01,{ }^{\# \# \#} p<0.001$ vs. $\mathrm{H}_{2} \mathrm{O}_{2}$ only treated group.

and restores ARPE-19 cells from $\mathrm{H}_{2} \mathrm{O}_{2}$-induced apoptotic cell damage through $\mathrm{Bcl} 2 / \mathrm{Bax} /$ caspases associated with signaling pathways.

3.3. Tribulus terrestris Affects $\mathrm{H}_{2} \mathrm{O}_{2}$-Induced Intracellular ROS and SOD Activities in ARPE-19 Cells. Many studies have demonstrated that oxidative stress leads to reactive oxygen species (ROS) production beyond the limits of clearance in vivo and causes oxidation and antioxidant system imbalance, which results in functional and morphological impairments of retinal pigment epithelium (RPE), endothelial cells, and retinal ganglion cells [31]. In addition, superoxide dismutase (SOD) is one of the most important antioxidant enzymes of the intracellular antioxidant defense system. SOD can remove oxygen-free radicals and protect cells from oxidative injury and the level of SOD activity reflects the cellular antioxidant ability. Therefore, we were interested to investigate whether EE-TT could restore the oxidative injury of ARPE-19 cells induced by $\mathrm{H}_{2} \mathrm{O}_{2}$-treatment. In Figures 4(a) and 4(b), ROS and SOD activities were measured in ARPE19 cells with EE-TT treatment after exposure to $\mathrm{H}_{2} \mathrm{O}_{2}$ for $24 \mathrm{~h}$. In Figure 4(a), the data shows that $\mathrm{H}_{2} \mathrm{O}_{2}$ induced a clear increase of intracellular ROS activities compared with non$\mathrm{H}_{2} \mathrm{O}_{2}$-treated sample (mean of fluorescence intensity, MFI, from 8.4 to 281); treatment with EE-TT remarkably decreased the upregulated ROS activities induced by $\mathrm{H}_{2} \mathrm{O}_{2}$ in a dose-dependent manner (mean of fluorescence intensity, MFI, from 281 to 93,15 , respectively). We also observed that $\mathrm{H}_{2} \mathrm{O}_{2}$ treatment significantly reduced $42 \%$ of the intracellular $\mathrm{SOD}$ activities compared with non- $\mathrm{H}_{2} \mathrm{O}_{2}$-treated sample; and treatment with 100 or $200 \mu \mathrm{g} / \mathrm{mL}$ EE-TT noticeably enhanced the downregulated SOD activities induced by $\mathrm{H}_{2} \mathrm{O}_{2}$ (Figure 4(b)).

In addition, a comparison of antioxidant activity between EE-TT and vitamin E (a positive antioxidant control) was performed to determine the antioxidant capacity of EE-TT itself (Figure 4(c)); the results show that the antioxidant capacity of $200 \mu \mathrm{g} / \mathrm{mL}$ EE-TT is higher than that of $200 \mu \mathrm{M}$ 


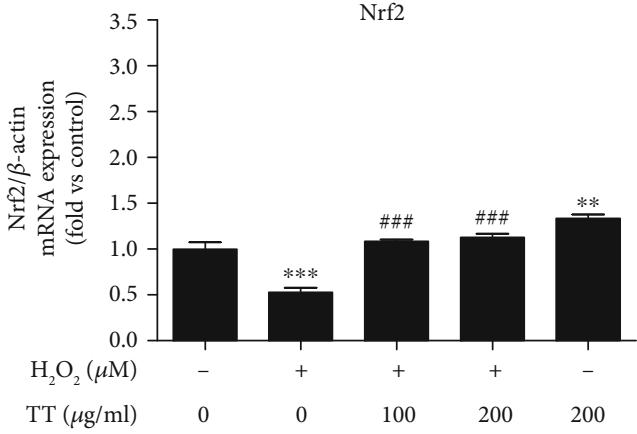

(a)

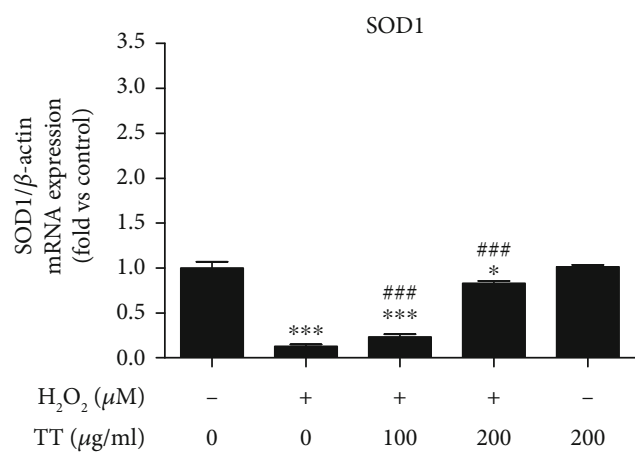

(c)

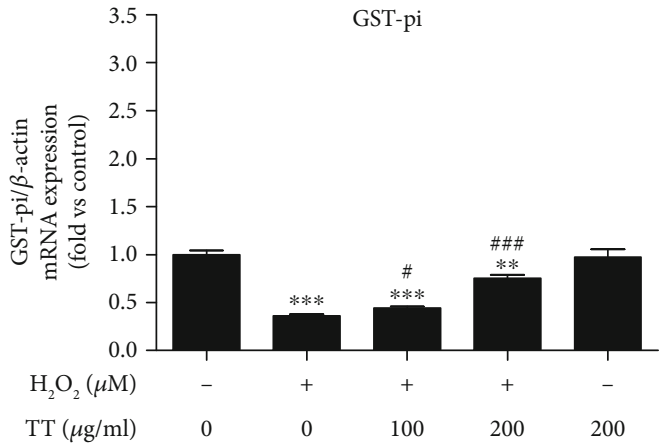

(e)

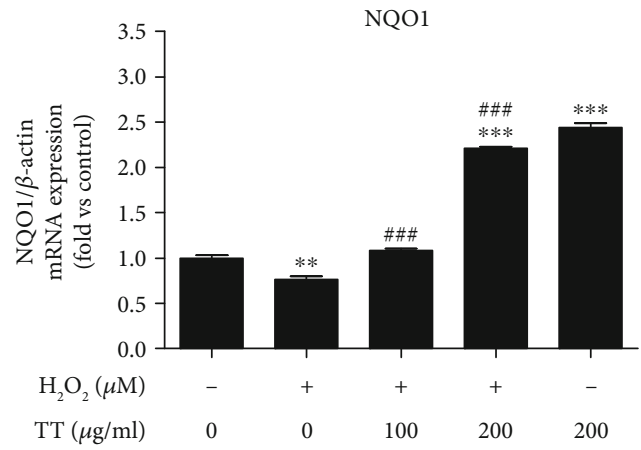

(g)

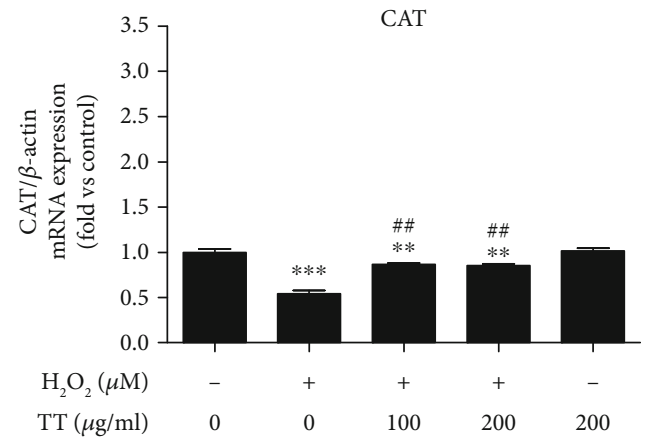

(b)

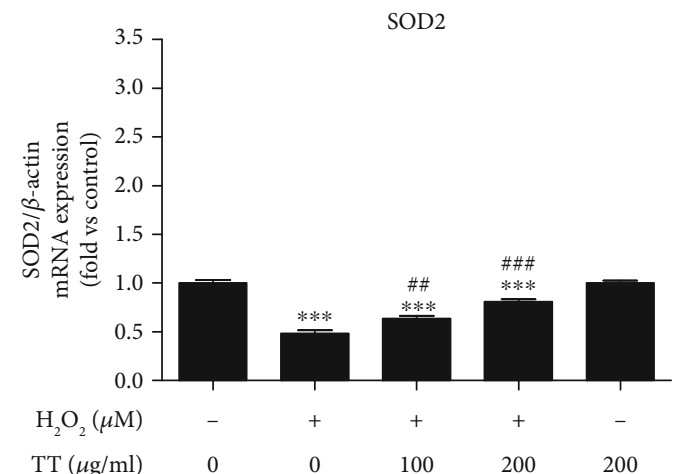

(d)

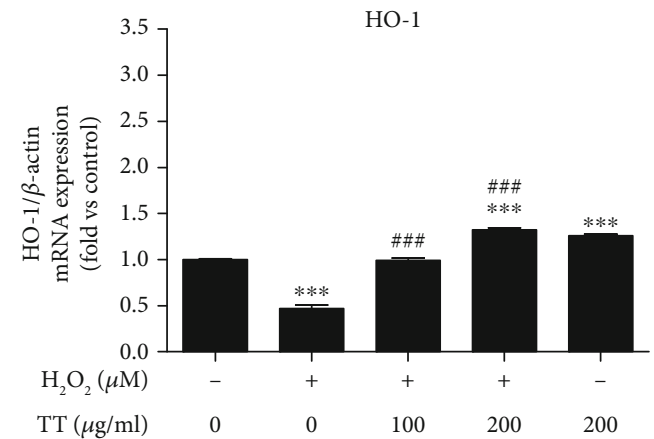

(f)

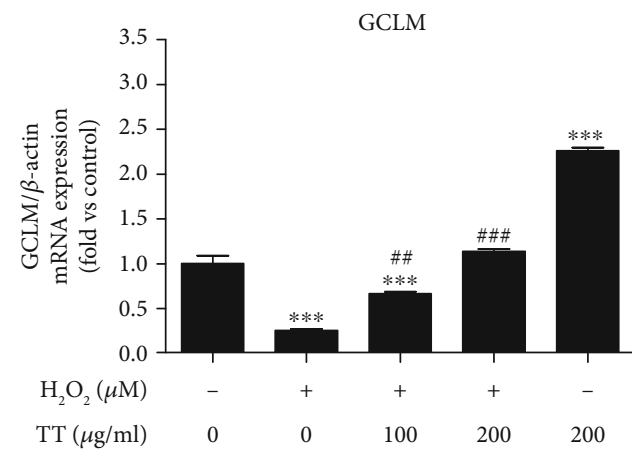

(h)

FIgURE 5: Effects of EE-TT on mRNA expression levels of rodex-related genes in $\mathrm{H}_{2} \mathrm{O}_{2}$-treated ARPE-19 cells. ARPE-19 cells were pretreated with or without $1 \mathrm{mM} \mathrm{H}_{2} \mathrm{O}_{2}$ for $24 \mathrm{~h}$, followed by a $24 \mathrm{~h}$ exposure to ethanol extracts of Tribulus terrestris (EE-TT). The mRNA expression levels of Nrf2 (a), CAT (b), SOD1 (c), SOD2 (d), GST-pi (e), HO-1 (f), NQO1 (g), and GCLM (h) for each sample were measured by real-time PCR; the fold changes of each gene are shown in the bar graph compared with the control sample (nontreated cells, value of 1). The data are shown as mean $\pm \mathrm{SD},{ }^{*} p<0.05,{ }^{* *} p<0.01,{ }^{* * *} p<0.001$ vs. the control sample (non-treated cells); ${ }^{\#} p<0.05,{ }^{\# \#} p<0.01,{ }^{\# \# \#} p<0.001$ vs. the sample with $\mathrm{H}_{2} \mathrm{O}_{2}$ only treated sample. 


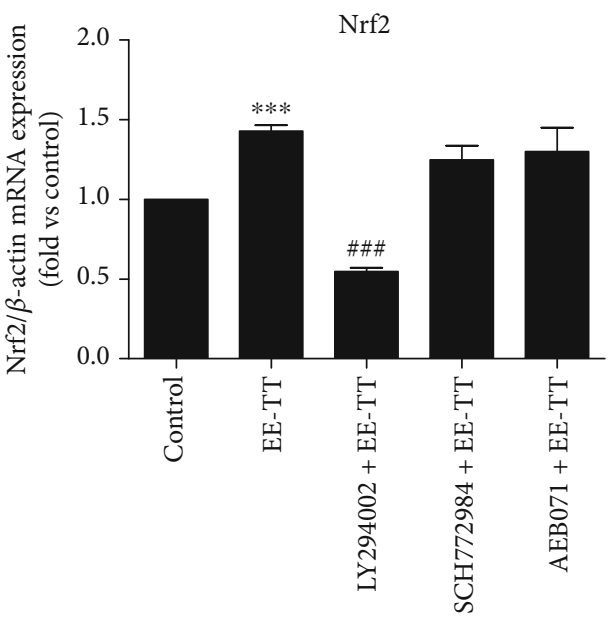

(a)

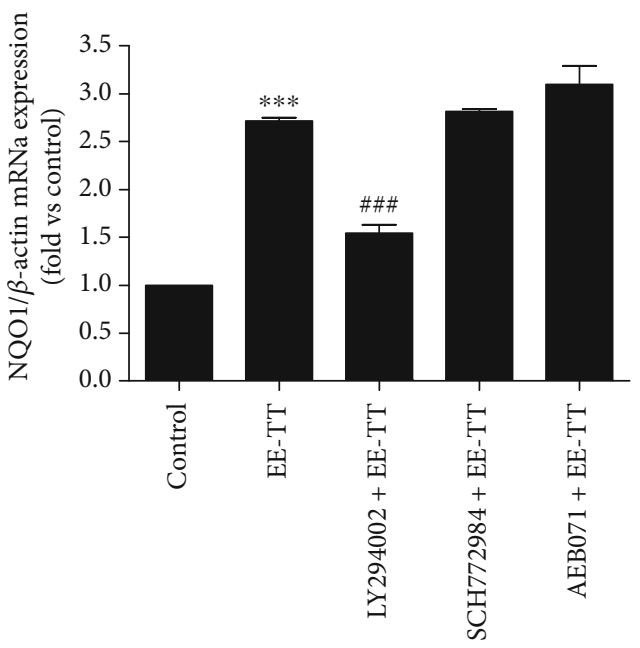

(c)

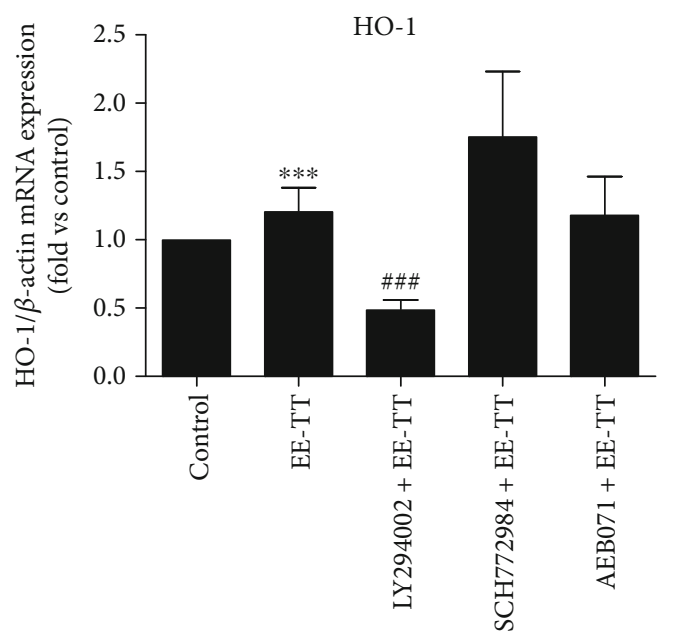

(b)

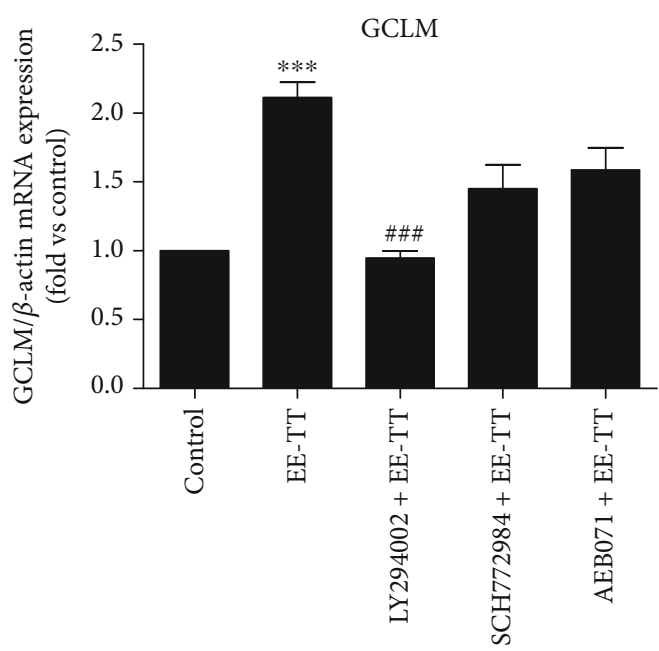

(d)

FIGURE 6: Inhibitor of PI3K/Akt signaling pathway blocked the upregulation of mRNA expression levels of Nrf2, HO-1, NQO1, and GCLM

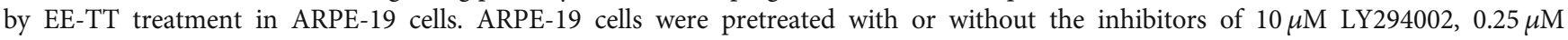
SCH772984, and $0.5 \mu \mathrm{M}$ of AEB071 for $1 \mathrm{~h}$, followed by a $24 \mathrm{~h}$ exposure to $200 \mu \mathrm{g} / \mathrm{mL}$ EE-TT. The mRNA expression levels of Nrf2 (a), HO-1(b), NQO1 (c), and GCLM (d) for each sample were measured by real-time PCR, and the fold changes of each gene are shown in the bar graph compared with the control sample (nontreated cells, value of 1 ). All data are shown as mean $\pm \mathrm{SD},{ }^{*} p<0.05,{ }^{* *} p<0.01,{ }^{* * *} p<$ 0.001 vs. the control sample (nontreated cells); ${ }^{\#} p<0.05,{ }^{\# \#} p<0.01,{ }^{\# \# \#} p<0.001$ vs. the sample with EE-TT treated only cells.

Trolox (an analogue of vitamin E, a positive antioxidant control), while both results showed the similar levels of cell viability after treating the cells for $24 \mathrm{~h}$ on oxidative stressed ARPE-19 cells (data not shown). In sum, the above results show that ethanol extracts of Tribulus terrestris (EE-TT) could effectively affect the oxidation and antioxidant imbalanced system induced by $\mathrm{H}_{2} \mathrm{O}_{2}$ through the regulations of both activities of ROS and SOD in ARPE-19 cells.

\subsection{The Activation of Tribulus terrestris on the $m R N A$} Expressions of Nrf2 and Its Target Genes in ARPE-19 Cells. As demonstrated above, Tribulus terrestris protected ARPE-19 cells against oxidative stress by inhibiting $\mathrm{H}_{2} \mathrm{O}_{2}$ induced ROS production and apoptosis, thereby noticeably improved the cell viability. An increasing number of studies have reported that the activation of the transcription factor NRF2 (nuclear factor erythroid 2-related factor 2) signaling pathway may be involved in the antioxidant responses against the oxidative stress in ARPE-19 cells, especially through regulation of its target genes which encoding phase II enzymes including HO-1, SOD, NQO1, and GCLM [32-34]. We then investigated whether ethanol extracts of Tribulus terrestris (EE-TT) could regulate the mRNA expression level of $\mathrm{Nrf} 2$ and its target genes under both conditions with or without $\mathrm{H}_{2} \mathrm{O}_{2}$-treatment. In Figure 5, the ARPE-19 cells were pretreated with or without $1 \mathrm{mM} \mathrm{H}_{2} \mathrm{O}_{2}$, then cells were treated with or without EE-TT for $24 \mathrm{~h}$; the mRNA levels of Nrf2, CAT, SOD1, SOD2, GST-pi, HO-1, NQO1, and GCLM were measured by real-time PCR. As shown in Figure 5, treatment with $1 \mathrm{mM} \mathrm{H}_{2} \mathrm{O}_{2}$ alone for $24 \mathrm{~h}$ significantly decreased the Nrf2, CAT, SOD1, SOD2, GST-pi, HO-1, NQO1, and GCLM mRNA expression levels compared with the untreated control sample. Also, EE-TT treatment noticeably restored all of these enzymes or proteins 
mRNA expression levels in $\mathrm{H}_{2} \mathrm{O}_{2}$-treated ARPE-19 cells. Furthermore, treatment with $200 \mu \mathrm{g} / \mathrm{mL}$ EE-TT alone on ARPE-19 cells for $24 \mathrm{~h}$ remarkably upregulated Nrf2, HO-1, NQO1, and GCLM mRNA expression levels about 1.33, $1.26,2.44$, and 2.25 folds, respectively. These results suggest that EE-TT may activate Nrf2 signaling through the upregulation of its mRNA expression levels.

3.5. Tribulus terrestris Upregulated the mRNA Expression Levels of Nrf2, HO-1, NQO1, and GCLM through PI3K/Akt Signaling Pathway in ARPE-19 Cells. The previous studies have reported that the regulation or activation of Nrf2-ARE signaling may be through PI3K/Akt (phosphoinositide 3kinase and AKT serine/threonine kinase 1), ERK/MAPK, or PKC signaling pathways [35-37]; we thus detected which signaling pathways are involved in the regulation of EE-TT on NRF2 and its associated antioxidant genes expressions. In Figure 6, ARPE-19 cells were treated with or without the inhibitors of PI3K/Akt (LY 294002), ERK1/2 (SCH772984), or PKC (AEB071) for $2 \mathrm{~h}$ before being exposed to $200 \mu \mathrm{g} / \mathrm{mL}$ $\mathrm{EE}-\mathrm{TT}$ for $24 \mathrm{~h}$; the mRNA expression levels were measured by real-time PCR. The results demonstrate that pretreatment with the inhibitor of PI3K/Akt (LY294002) clearly eliminated the upregulation of mRNA expressions of Nrf2, HO-1, NQO1, and GCLM genes in ARPE-19 cells.

3.6. Tribulus terrestris Enhanced the Cell Viability of Oxidative Stressed ARPE-19 Cells through PI3K/Akt Signaling Pathway. In order to examine whether the inhibition of PI3K/Akt signaling pathway could also accordingly affect the cell survival of $\mathrm{H}_{2} \mathrm{O}_{2}$-treated ARPE-19 cells, in Figure 7, after ARPE-19 cells were treated with or without $1 \mathrm{mM} \mathrm{H}_{2} \mathrm{O}_{2}$ for $24 \mathrm{~h}$, the cells were then pretreated with the inhibitors for $1 \mathrm{~h}$, followed by treatment with $200 \mu \mathrm{g} / \mathrm{mL}$ EE-TT for $24 \mathrm{~h}$; the viability of cells was measured by MTS assay. As shown in Figure 7, the result indicates that pretreatment with the inhibitor of PI3K/Akt (LY 294002) signaling pathway significantly blocked the increased cell viability induced by EE-TT treatment.

3.7. Tribulus terrestris Activated the Nrf2 Protein Translocation to the Nuclear. To further investigate the antioxidant mechanisms of Tribulus terrestris on oxidative stressed ARPE-19 cells, we tested whether EE-TT could promote the Nrf2 translocation to the nucleus and activate the Nrf2 signaling. ARPE-19 cells were pretreated with or without $1 \mathrm{mM} \mathrm{H} \mathrm{H}_{2} \mathrm{O}_{2}$ for $24 \mathrm{~h}$, followed by a $24 \mathrm{~h}$ exposure to EE-TT ( 100 or $200 \mu \mathrm{g} / \mathrm{mL}$ ), then the cytoplasm (a) or the nucleus protein (b) was analyzed using Western blot assay with the antibodies of $\operatorname{Nrf} 2, \beta$-actin, or histone H3. First, as shown in Figure 8, treatment with $1 \mathrm{mM} \mathrm{H}_{2} \mathrm{O}_{2}$ alone for $24 \mathrm{~h}$ significantly decreased the cytoplasm Nrf2 protein level while increased the nuclear Nrf2 protein level. Furthermore, EE-TT remarkably promoted the Nrf2 protein translocation from cytoplasm to the nuclear in a dose-dependent manner. In addition, ARPE-19 cells treatment with $200 \mu \mathrm{g} / \mathrm{mL}$ EE-TT alone for $24 \mathrm{~h}$ had no significant effect on the Nrf2 protein expressions neither in the cytoplasm nor in the nucleus.

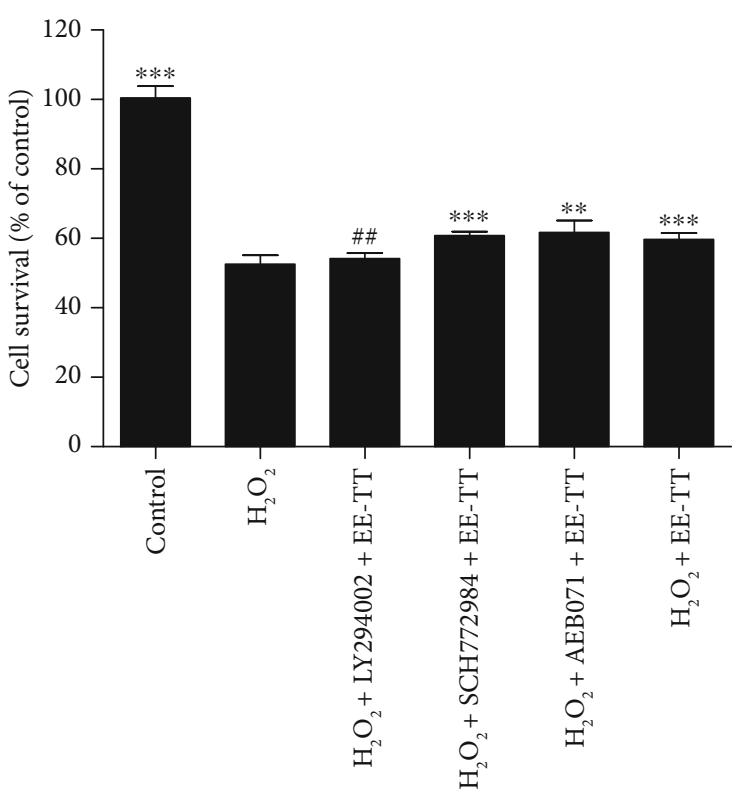

Figure 7: Tribulus terrestris increased the cell viability of oxidative stressed ARPE-19 cells through PI3K/Akt signaling pathway. ARPE-19 cells were treated with or without $1 \mathrm{mM} \mathrm{H}_{2} \mathrm{O}_{2}$ for $24 \mathrm{~h}$, then cells were exposed to $200 \mu \mathrm{g} / \mathrm{mL}$ EE-TT after $1 \mathrm{~h}$ treatment with the inhibitors of $10 \mu \mathrm{M}$ LY294002, or $0.25 \mu \mathrm{M}$ SCH772984, or $0.5 \mu \mathrm{M}$ of AEB071, respectively. The viability of cells was measured by the MTS assay and was expressed as a percentage of the control group (nontreated cells). All data are shown as mean $\pm \mathrm{SD},{ }^{*} p<0.05,{ }^{* *} p<0.01,{ }^{* * *} p<0.001$ vs. the sample with $\mathrm{H}_{2} \mathrm{O}_{2}$ treated only cells; ${ }^{\#} p<0.05,{ }^{\# \#} p<0.01$ vs. the sample with $\mathrm{H}_{2} \mathrm{O}_{2}$ and EE-TT treated cells.

\section{Discussion}

In recent years, there have been more and more reports about the relations between oxidative stress and ophthalmic diseases. Oxidative stress has been found to induce or accelerate pathological progression in some ophthalmic diseases (including dry eye, $\mathrm{AMD}$, and $\mathrm{DR}$ ) $[6,38,39]$. In fact, there are many studies that focus on examining the effects of oxidative stress on the development of AMD diseases using in vitro and in vivo experiments [34, 40, 41]. In addition, it has been reported in one clinical research that the serum level of total oxidant status (TOS, an oxidative stress parameter) was significantly increased by about $167 \%$ in 22 AMD patients when compared with that of a group of 25 healthy people, while the levels of two important antioxidant molecules (total thiol status (TTS) and the activity of paraoxonase $1(\mathrm{PON} 1)$ ) were significantly decreased. Based on these results, it can be stated that increased oxidative stress and decreased antioxidant levels may have a synergistic role in AMD development [42]. Another clinical trial has evaluated the effects of several antioxidant agents on the progression of AMD and visual acuity. This trial was carried out using pharmacological doses, including $\beta$-carotene, vitamin $\mathrm{C}$, vitamin $\mathrm{E}$, zinc, and copper. Their data demonstrated that the administration of antioxidants could result in a $25 \%$ risk reduction in advanced AMD progression and a $19 \%$ risk reduction in moderate vision loss within 5 years [43]. In light of these results, it 


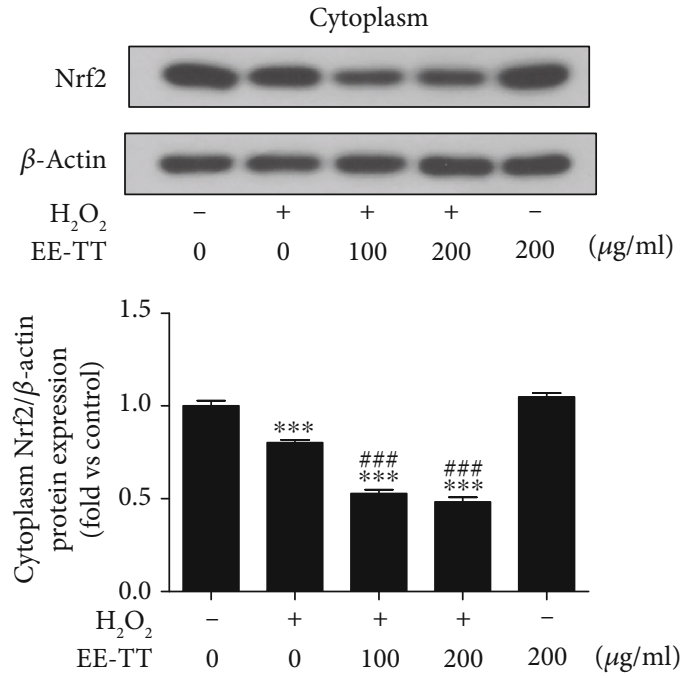

(a)

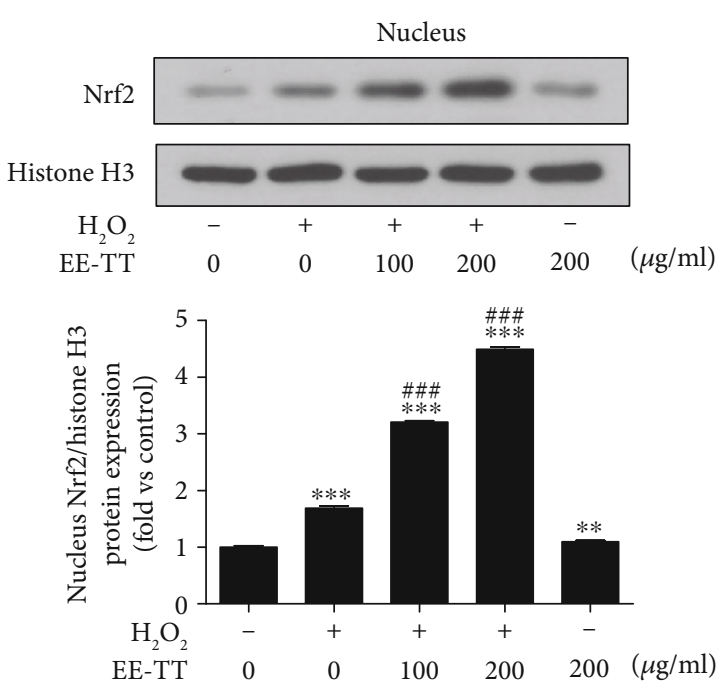

(b)

FIGURE 8: EE-TT promotes the nuclear translocation of $\mathrm{Nrf2}$ in $\mathrm{H}_{2} \mathrm{O}_{2}$-treated ARPE-19 cells. ARPE-19 cells were pretreated with or without $1 \mathrm{mM} \mathrm{H}_{2} \mathrm{O}_{2}$ for $24 \mathrm{~h}$, followed by a $24 \mathrm{~h}$ exposure to ethanol extracts of Tribulus terrestris (EE-TT). The results of Western blot analyses for protein abundance of Nrf2 in the cytoplasm (a) and nucleus (b) with quantification data are showed and the fold changes vs. control sample (nontreatment) are presented in the bar graph. Data are shown as mean $\pm \mathrm{SD},{ }^{*} p<0.05,{ }^{* *} p<0.01,{ }^{* * *} p<0.001$ vs. the nontreatment control sample; ${ }^{\#} p<0.05,{ }^{\# \#} p<0.01,{ }^{\# \# \#} p<0.001$ vs. the sample with $\mathrm{H}_{2} \mathrm{O}_{2}$ treatment alone.

has been demonstrated that the use of antioxidants for the treatment or adjuvant treatment of AMD disease is a prospective therapeutic treatment.

The main active ingredients of Tribulus terrestris (TT) are saponins, flavonoids, alkaloids, amino acids, and the others (such as glycosides, fatty acids, and vitamins) [44]. Many studies have shown that saponins and flavonoids in TT are the main contributors of its pharmacological benefits including having aphrodisiac, anti-inflammatory, antimicrobial, and antioxidant abilities [45]. Although natural saponins and flavonoids usually have low oral bioavailability (the blood concentration is from nanomolar to micromolar), there are studies that have shown that oral administration of saponins or flavonoids could significantly improve ocular symptoms of certain retinal diseases (such as diabetic retinopathy and retinal vein occlusion), which were confirmed by the in vivo animal experiments or the clinical trials $[46,47]$. These results suggest that some natural products or their metabolites may function by circulating blood into the retina. Saponins are one of the primary components identified in TT and, so far, about 108 kinds of steroidal saponins have been isolated from TT. Among these, protodioscin and protogracillin are thought to confer TT's unique biological activities [46]. The main pharmacological activities of saponins in TT include its effects on lowering blood pressure, lowering blood lipid, and protecting the cardiovascular system against myocardial ischemia [47-49]; improving the apoptosis rate of ischemic brain nerve cells, protecting brain nerve, enhancing memory and antidepressant effect, reducing blood glucose and diabetes-induced apoptosis of optic nerve cells in diabetic mice [50-53]. Some studies have reported that the saponins from TT could improve primary mice retinal ganglion cells (RGCs) survival when cultured in vitro $[38,54]$. Today, saponins from TT are used for sequelae of cerebrovascular disease and coronary heart disease treatments [55-57]. As the main active ingredient of TT, the main flavonoids extracted from Tribulus terrestris include quercetin, kaempferol, isorhamnetin, and their derivatives according to their skeleton structures [36]. In recent years, the natural flavonoids from many edible plants (such as vegetables, fruits, and beans) or from traditional herb medicines have become a subject of interest due to their potent antioxidant capacity and low toxicity, which in return, makes them highly effective as potential therapeutic agents. In natural flavonoids, quercetin appears to be the subject of the most studies in different tissues or cell types, and the protective effects of quercetin against oxidative-induced damages in ARPE-19 cells have also been reported [34, 57] with the activation of Nrf2 pathway and its target genes implicated in antioxidant defense. Kaempferol is a member of the flavonols family, widely found in many edible plants and traditional herb medicines (such as chrysanthemum, astragalus mongholicus, ginkgo leaf, and dry raspberry). In 2018, our group reported that kaempferol has stronger antioxidant activity than that of lutein and resveratrol. Our data illustrated that the nanomole concentration of kaempferol has significant effects on improving the oxidative damage of ARPE-19 cells or rat RPE cells tested by in vitro or in vivo experiments. We also demonstrated that treatment with kaempferol significantly reduced the upregulated ROS activity while increasing the SOD activity, as well as inhibited the apoptosis by regulating the $\mathrm{Bcl} 2, \mathrm{Bax}$, and caspase- 3 proteins expressions in $\mathrm{H}_{2} \mathrm{O}_{2}$-treated ARPE-19 cells [27]. Isorhamnetin is also a common flavonoid found in nature. The protective effects of isorhamnetin on oxidative stressed ARPE-19 cells were also reported by Liao et al. [53] in 2009. They found that isorhamnetin pretreatment significantly increased the phosphorylation of phosphoinositide 3-kinase (PI3K) 
and AKT serine/threonine kinase 1 (Akt) in ARPE-19 cells exposed to $\mathrm{H}_{2} \mathrm{O}_{2}$ compared with cells treated with $\mathrm{H}_{2} \mathrm{O}_{2}$ alone, suggesting that the protective effects of isorhamnetin on oxidative stressed ARPE-19 cells might be through PI3k/Akt associated signaling pathway.

Numerous reports have proved that Nrf2 is an emerging regulator of cellular resistance to oxidative stress. Some natural products (such as apigenin, quercetin, gypenosides, genipin, rhizoma paridis, escin, and astaxanthin) have also been shown to have protective effects against the oxidative stressed ARPE-19 cells associated with Nrf2 signaling [28, 57-63]. In our study, we found that treatment with $1 \mathrm{mM} \mathrm{H}_{2} \mathrm{O}_{2}$ for $24 \mathrm{~h}$ significantly induced a serious oxidative cell damage and apoptosis in ARPE-19 cells (Figures 1 and 2). In the meantime, the mRNA expressions of Nrf2 and its target genes encoding phase II metabolizing enzymes and antioxidases (such as CAT, HO-1, SOD1, SOD2, GST-pi, NQO1, and GCLM) were also remarkably decreased by $\mathrm{H}_{2} \mathrm{O}_{2}$ when compared with control cells (Figure 5). These results are very similar to those of another group's work [59] in which they also used the high concentration $(750 \mu \mathrm{M})$ of $\mathrm{H}_{2} \mathrm{O}_{2}$ to induce oxidative stressed model in ARPE-19 cells. Although, in the studies of another two groups who investigated the protective effects of apigenin [28] or quercetin [57] on tBHP or $\mathrm{H}_{2} \mathrm{O}_{2}$ induced oxidative stressed model in ARPE-19 cells, treatment with $200 \mu \mathrm{M} \mathrm{H}_{2} \mathrm{O}_{2}$ alone did not change the Nrf2 mRNA expression. Though, the nuclear Nrf2 protein expression was increased and the mRNA expression levels of phase II enzymes and antioxidases (such as HO-1, NQO1, and GCL) were upregulated as well. These results suggest that the Nrf2 signaling was activated [57]. Combined with all the above results, it is clear that the high concentration of $\mathrm{H}_{2} \mathrm{O}_{2}$ may induce serious oxidative stress and thereby inhibiting the Nrf2 mRNA expression and Nrf2 activation. However, treatment with a low concentration of $\mathrm{H}_{2} \mathrm{O}_{2}(200 \mu \mathrm{M})$ may induce mild oxidative stress and could induce the activation of $\mathrm{Nrf} 2$, resulting in the increase of mRNA and protein expressions of phase II enzymes and antioxidases. In our study, treatment with EE-TT in the absence of $\mathrm{H}_{2} \mathrm{O}_{2}$ also increased the mRNA expressions of Nrf2 and the phase II enzymes and antioxidases (including NQO1, GCLM, and HO-1, but not for CAT, SODs, and GST-pi) (Figure 5). These results are similar to those of the other experiments, which treatment ARPE-19 cells with apigenin [28], genipin [60], escin [62], or astaxanthin [63], respectively. The underlying mechanisms involved in this regulation might be cell type or oxidant type dependent [7, 26, 28, 37, 49, 64]. Furthermore, treatment with EE-TT significantly increased the translocation of $\mathrm{Nrf} 2$ to the nucleus, as well as restored the downregulated mRNA expression levels of Nrf2 and phase II enzymes and antioxidases in $\mathrm{H}_{2} \mathrm{O}_{2}$-treated ARPE-19 cells (Figures 5 and 8). This suggests that the components of EETT could affect Nrf2-ABE signaling not only under normal condition but also under the oxidative stress condition.

In summary, our study shows for the first time that ethanol extracts of Tribulus terrestris (EE-TT) exhibit potent protective effects on ARPE-19 cells against $\mathrm{H}_{2} \mathrm{O}_{2}$-induced oxidative injury, which are associated with its antioxidant effects dependent on the activation of PI3K/Akt -Nrf2 signal- ing. Our current study strongly demonstrates that Tribulus terrestris could be a safe preventive and therapeutic option for patients with AMD or other retinal diseases patients.

\section{Data Availability}

Please contact Dr. Donglei Zhang if somebody needs the data or information about this manuscript. Please e-mail to: zhangdonglei@huh.edu.cn.

\section{Conflicts of Interest}

The author(s) declare(s) that they have no conflicts of interest.

\section{Acknowledgments}

We are grateful to Professor Zhan-Lin Li of the School of Traditional Chinese Meteria Medica, Shenyang Pharmaceutical University, for assisting the EE-TT preparation. Dr. Donglei Zhang and Dr. Wei He are the cocorresponding authors. This work was partially supported by grants from the Natural Science Foundation of Technology Department of Liaoning Province of China (20180550378) and the Science and Technology Program of Liaoning (grant numbers 2019JH2/10300011).

\section{References}

[1] R. Bruninx, "Retinitis pigmentosa," Review Medicine Liege, vol. 75, no. 2, pp. 73-74, 2020.

[2] W. Wang and A. Lo, "Diabetic retinopathy: pathophysiology and treatments," International Journal of Molecular Sciences, vol. 19, no. 6, pp. 1816-1830, 2018.

[3] R. Simó, M. Villarroel, L. Corraliza, C. Hernández, and M. Garcia-Ramírez, "The Retinal Pigment Epithelium: Something More than a Constituent of the Blood-Retinal Barrier-Implications for the Pathogenesis of Diabetic Retinopathy," Journal of Biomedicine and Biotechnology, vol. 2010, 15 pages, 2010.

[4] O. Strauss, "The retinal pigment epithelium in visual function," Physiological Reviews, vol. 85, no. 3, pp. 845-881, 2005.

[5] S. Khandhadia and A. Lotery, "Oxidation and age-related macular degeneration: insights from molecular biology," Expert Reviews in Molecular Medicine, vol. 12, article e34, 2010.

[6] S. Beatty, H.-H. Koh, M. Phil, D. Henson, and M. Boulton, "The role of oxidative stress in the pathogenesis of agerelated macular degeneration," Survey of Ophthalmology, vol. 45, no. 2, pp. 115-134, 2000.

[7] K. R. Li, S. Q. Yang, Y. Q. Gong et al., "3H-1,2-dithiole-3thione protects retinal pigment epithelium cells against ultraviolet radiation via activation of Akt-mTORC1-dependent Nrf2-HO-1 signaling," Science Reprots, vol. 6, 2016.

[8] C. Zhang, L. Shu, and A.-N. T. Kong, "MicroRNAs: new players in cancer prevention targeting Nrf2, Oxidative Stress and Inflammatory Pathways," Current Pharmacology Reports, vol. 1, no. 1, pp. 21-30, 2015.

[9] M. K. Kwak, P. A. Egner, P. M. Dolan, M. Ramos-Gomez, J. D. Groopman, and K. Itoh, "Role of phase 2 enzyme induction in chemoprotection by dithiolethiones," Mutation Research, vol. 305 , no. 15 , pp. 480-481, 2001. 
[10] I. Mirończuk-Chodakowska, A. M. Witkowska, and M. E. Zujko, "Endogenous non-enzymatic antioxidants in the human body," Advances in Medical Sciences, vol. 63, no. 1, pp. 68-78, 2018.

[11] K. Itoh, J. Mimura, and M. Yamamoto, "Discovery of the negative regulator of Nrf2, Keap1: a historical overview," Antioxidants \& Redox Signaling, vol. 13, no. 11, pp. 1665-1678, 2010.

[12] L. Baird and A. T. Dinkova-Kostova, "The cytoprotective role of the Keap1-Nrf2 pathway," Archives of Toxicology, vol. 85, no. 4, pp. 241-272, 2011.

[13] Y. Mitsuishi, H. Motohashi, and M. Yamamoto, "The Keap1Nrf2 system in cancers: stress response and anabolic metabolism," Frontiers in Oncology, vol. 2, no. 16, pp. 123-140, 2012.

[14] T. W. Kensler, N. Wakabayashi, and S. Biswal, "Cell survival responses to environmental Stresses Via the Keap1-Nrf2ARE pathway," Annual Review of Pharmacology and Toxicology, vol. 47, no. 1, pp. 89-116, 2007.

[15] A. Loboda, M. Damulewicz, E. Pyza, A. Jozkowicz, and J. Dulak, "Role of Nrf2/HO-1 system in development, oxidative stress response and diseases: an evolutionarily conserved mechanism," Cellular and Molecular Life Sciences, vol. 73, no. 17, pp. 3221-3247, 2016.

[16] Z. Zhao, Y. Chen, J. Wang et al., "Age-related retinopathy in NRF2-deficient mice," PLoS ONE, vol. 6, no. 4, 2011.

[17] M. Ni, X. Li, Z. Yin, H. Jiang, and M. Sidoryk-Wegrzynowicz, "Methylmercury induces acute oxidative stress, altering Nrf2 protein level in primary microglial cells," Toxicology Sciences, vol. 116, pp. 590-603, 2010.

[18] N. G. Innamorato, A. I. Rojo, A. J. Garcia-Yague, M. Yamamoto, and M. L. de Ceballos, "The transcription factor Nrf2 is a therapeutic target against brain inflammation," Journal of Immunology, vol. 181, pp. 680-689, 2008.

[19] A. I. Rojo, N. G. Innamorato, A. M. Martin-Moreno, M. L. De Ceballos, and M. Yamamoto, "Nrf2 regulates microglial dynamics and neuroinflammation in experimental Parkinson's disease," Glia, vol. 58, pp. 588-598, 2010.

[20] J. G. Hollyfield, V. L. Bonilha, M. E. Rayborn, X. Yang, and K. G. Shadrach, "Oxidative damage-induced inflammation initiates age-related macular degeneration," Nature Medicine, vol. 14, no. 2, pp. 194-198, 2008.

[21] S. Chhatre, T. Nesari, G. Somani, D. Kanchan, and S. Sathaye, "Phytopharmacological overview of Tribulus terrestris," Pharmacognosy Reviews, vol. 8, no. 15, pp. 45-51, 2014.

[22] N. B. Samani, A. Jokar, M. Soveid, M. Heydari, and S. H. Mosavat, "Efficacy of the hydroalcoholic extract of Tribulus terrestris on the serum glucose and lipid profile of women with diabetes mellitus: a double-blind randomized placebocontrolled clinical trial," Journal of Evidence-Based Complementary \& Alternative Medicine, vol. 21, no. 4, pp. 91-97, 2016.

[23] P. L. Reshma, P. Binu, N. Anupama et al., "Pretreatment of Tribulus terrestris L. causes anti-ischemic cardioprotection through MAPK mediated anti-apoptotic pathway in rat," Biomedicine \& Pharmacotherapy, vol. 111, pp. 1342-1352, 2019.

[24] S. F. GamalEl Din, M. A. Abdel Salam, M. S. Mohamed et al., "Tribulus terrestris versus placebo in the treatment of erectile dysfunction and lower urinary tract symptoms in patients with late-onset hypogonadism: a placebo-controlled study," Urologia, vol. 86, no. 2, pp. 74-78, 2018.

[25] H. Zhang, W.-T. Tong, C.-R. Zhang et al., "Gross saponin of Tribulus terrestris improves erectile dysfunction in type 2 dia- betic rats by repairing the endothelial function of the penile corpus cavernosum," Diabetes, Metabolic Syndrome and Obesity: Targets and Therapy, vol. Volume 12, pp. 1705-1716, 2019.

[26] X. Xie, J. Feng, Z. Kang et al., "Taxifolin protects RPE cells against oxidative stress-induced apoptosis," Molecular Vision, vol. 23, pp. 520-528, 2017.

[27] D. Weiwei, Y. An, X. He, D. Zhang, and W. He, "Protection of kaempferol on oxidative stress-induced retinal pigment epithelial cell damage," Oxidative Medicine and Cellular Longevity, vol. 2018, 14 pages, 2018.

[28] X. Xu, M. Li, W. Chen, H. Yu, Y. Yang, and L. Hang, "Apigenin attenuates oxidative injury in ARPE-19 cells thorough activation of Nrf2 pathway," Oxidative Medicine and Cellular Longevity, vol. 2016, 9 pages, 2016.

[29] E. Dinc, L. Ayaz, and A. H. Kurt, "Protective effect of combined caffeic acid phenethyl ester and bevacizumab against hydrogen peroxide-induced oxidative stress in human RPE cells," Current Eye Research, vol. 42, no. 12, pp. 718-725, 2017.

[30] N. Arend, C. Wertheimer, P. Laubichler, A. Wolf, A. Kampik, and M. Kernt, "Idebenone prevents oxidative stress, cell death and senescence of retinal pigment epithelium cells by stabilizing BAX/Bcl-2 ratio," Ophthalmologica, vol. 234, no. 2, pp. 7382, 2015.

[31] Y. He, K. W. Leung, Y. Ren, J. Pei, and J. Ge, "PEDF improves mitochondrial function in RPE cells during oxidative stress," Investigative Ophthalmology \& Visual Science, vol. 55, no. 10, pp. 6742-6755, 2014.

[32] Y. Cui, Y. Li, N. Huang et al., "Structure based modification of chalcone analogue activates Nrf2 in the human retinal pigment epithelial cell line ARPE-19," Free Radical Biology and Medicine, vol. 20, pp. 52-59, 2020.

[33] R. Cui, L. Tian, D. Lu, H. Li, and J. Cui, "Exendin-4 protects human retinal pigment epithelial cells from $\mathrm{H}_{2} \mathrm{O}_{2}$-induced oxidative damage via activation of NRF2 signaling," Ophthalmic Research, vol. 20, pp. 1-9, 2019.

[34] Y. Shao, H. Yu, Y. Yang, M. Li, L. Hang, and X. Xu, “A solid dispersion of quercetin shows enhanced Nrf2 activation and protective effects against oxidative injury in a mouse model of dry age-related macular degeneration," Oxidative Medicine and Cellular Longevity, vol. 2019, 12 pages, 2019.

[35] L. Wang, Y. Chen, P. Sternberg, and J. Cai, "Essential roles of the PI3 kinase/Akt pathway in regulating Nrf2-dependent antioxidant functions in the RPE," Investigative Ophthalmology \& Visual Science, vol. 49, no. 4, pp. 1671-1678, 2008.

[36] Y. Xu, L. Wang, L. Cao, L. Chen, and Q. Liu, "Involvement of NYD-SP15 in growth and oxidative-stress responses of ARPE19," Journal of Cellular Biochemistry, vol. 120, pp. 1362-1375, 2018.

[37] P. Su, J. Zhang, S. Wang et al., "Genistein alleviates leadinduced neurotoxicity in vitro and in vivo: Involvement of multiple signaling pathways," Neurotoxicology, vol. 53, pp. 153-164, 2016.

[38] S. Seen and L. Tong, "Dry eye disease and oxidative stress," Acta Ophthalmologica, vol. 96, pp. 412-420, 2018.

[39] G. D. Calderon, O. H. Juarez, G. E. Hernandez, S. M. Punzo, and Z. D. De la Cruz, "Oxidative stress and diabetic retinopathy: development and treatment," Eye, vol. 31, no. 8, pp. 11221130, 2017.

[40] K. Kaarniranta, J. Kajdanek, J. Morawiec, E. Pawlowska, and J. Blasiak, "PGC- $1 \alpha$ protects RPE cells of the aging retina 
against oxidative stress-induced degeneration through the regulation of senescence and mitochondrial quality control. The Significance for AMD Pathogenesis," International Journal of Molecular Sciences, vol. 19, no. 8, p. 2317, 2018.

[41] M. L. Fanjul-Moles and G. O. López-Riquelme, "Relationship between oxidative stress, circadian rhythms, and AMD," Oxidative Medicine and Cellular Longevity, vol. 2016, Article ID 7420637, 18 pages, 2016.

[42] N. Uğurlu, M. D. Aşık, F. Yülek, S. Neselioglu, and N. Cagil, "Oxidative stress and anti-oxidative defence in patients with age-related macular degeneration," Current Eye Research, vol. 38, no. 4, pp. 497-502, 2013.

[43] C. S. Sackett and S. Schenning, "The age-related eye disease study: the results of the clinical trial," Clinical Trial, vol. 27, pp. 5-7, 2002.

[44] W. Zhu, Y. Du, H. Meng, Y. Dong, and L. Li, "A review of traditional pharmacological uses, phytochemistry, and pharmacological activities of Tribulus terrestris," Chemistry Central Journal, vol. 11, no. 1, p. 60, 2017.

[45] S. Hemalatha and R. Hari, "Comparative antioxidant activities of crude ethanolic and saponin rich butanol extracts of Tribulus terrestris fruits," International Journal of Pharmacy and Biological Sciences, vol. 4, pp. 784-793, 2014.

[46] W. Zheng, F. Wang, Z. Yang et al., "Rapid characterization of constituents in Tribulus terrestris from different habitats by UHPLC/Q-TOF MS," Journal of The American Society for Mass Spectrometry, vol. 28, no. 11, pp. 2302-2318, 2017.

[47] Y. Ma, Z. Guo, and X. Wang, "Tribulus terrestris extracts alleviate muscle damage and promote anaerobic performance of trained male boxers and its mechanisms: roles of androgen, IGF-1, and IGF binding protein-3," The Journal of Sport and Health Science, vol. 12, pp. 1-8, 2015.

[48] V. Neychev and V. Mitev, "Pro-sexual and androgen enhancing effects of Tribulus terrestris L.: fact or fiction," Journal of Ethnopharmacology, vol. 179, pp. 345-355, 2015.

[49] P. L. Reshma, N. S. Sainu, A. K. Mathew, and K. G. Raghu, "Mitochondrial dysfunction in $\mathrm{H} 9 \mathrm{c} 2$ cells during ischemia and amelioration with Tribulus terrestris L.," Life Sciences, vol. 152, pp. 220-230, 2016.

[50] I. Kostova and D. Dinchev, "Saponins in Tribulus terrestris chemistry and bioactivity," Phytochemistry Reviews, vol. 4, no. 2-3, pp. 111-137, 2005.

[51] I. Noda, "Two-dimensional infrared spectroscopy," Journal of the American Chemical Society, vol. 11, pp. 8166-8188, 1989.

[52] I. Noda and Y. Ozaki, Two-dimensional correlation spectroscopy-applications in vibrational and optical spectroscopy, vol. 1, John Wiley\&Sons Ltd, USA, 2004.

[53] M. Y. Liao, L. N. Huang, and P. Zeng, "Effect of Tribulus terrestris L. on the retinal ganglion cells," International Eye Science, vol. 9, pp. 282-283, 2009.

[54] L. B. Li, J. Li, and H. Li, "Protective effects of gross saponins of Tribulus terrestris on experimental intracerebral hemorrhage in rats," Journal Harbin Medical University, vol. 40, pp. 99102, 2006.

[55] G. D. Wang and S. G. Sun, "Effects of Tribulus terrestris saponins for injection on treatment of coronary heart disease and angina pectoris," Chinese Journal of Gerontology, vol. 32, pp. 1480-1481, 2012.

[56] B. Wang, L. Ma, and T. Liu, "406 Cases of Angina pectoris in coronary heart disease treated with saponin of Tribulus terrestris," Zhong Xi Yi Jie He Za Zhi, vol. 10, pp. 85-87, 1990.
[57] X.-R. Xu, H.-T. Yu, Y. Yang, L. Hang, X.-W. Yang, and S.H. Ding, "Quercetin phospholipid complex significantly protects against oxidative injury in ARPE-19 cells associated with activation of Nrf2 pathway," European Journal of Pharmacology, vol. 770, pp. 1-8, 2016.

[58] J. Wang, H. M. Gong, H. H. Zou, L. Liang, and X. Y. Wu, "Isorhamnetin prevents $\mathrm{H}_{2} \mathrm{O}_{2}$ induced oxidative stress in human retinal pigment epithelial cells," Molecular Medicine Reports, vol. 17, no. 1, pp. 648-652, 2018.

[59] R. H. Alhasani, L. Biswas, A. M. Tohari et al., "Gypenosides protect retinal pigment epithelium cells from oxidative stress," Food and Chemical Toxicology, vol. 112, pp. 76-85, 2018.

[60] H. Zhao, R. Q. Wang, and L. Zhang, "Genipin protects against $\mathrm{H}_{2} \mathrm{O}_{2}$-induced oxidative damage in retinal pigment epithelial cells by promoting Nrf2 signaling," International Journal of Molecular Medicine, vol. 43, no. 2, pp. 936-944, 2019.

[61] B. Zhao, Z. Wang, J. Han, G. Wei, B. Yi, and Z. Li, "Rhizoma paridis total saponins alleviate $\mathrm{H}_{2} \mathrm{O}_{2}$-induced oxidative stress injury by upregulating the Nrf2 pathway," Molecular Medicine Reports, vol. 21, no. 1, pp. 220-228, 2020.

[62] K. Wang, Y. Jiang, W. Wang, J. Ma, and M. Chen, "Escin activates AKT-Nrf2 signaling to protect retinal pigment epithelium cells from oxidative stress," Biochemical and Biophysical Research Communications, vol. 468, pp. 1-7, 2015.

[63] Z. Li, X. Dong, H. Liu et al., "Astaxanthin protects ARPE-19 cells from oxidative stress via upregulation of Nrf2-regulated phase II enzymes through activation of PI3K/Akt," Molecular Vision, vol. 19, pp. 1656-1666, 2013.

[64] Z. Feng, Z. Liu, X. Li et al., " $\alpha$-Tocopherol is an effective Phase II enzyme inducer: protective effects on acrolein-induced oxidative stress and mitochondrial dysfunction in human retinal pigment epithelial cells," Journal of Nutritional Biochemistry, vol. 21, no. 12, pp. 1222-1231, 2010. 